\author{
RICHARD B. FREEMAN* \\ University of Chicago and \\ Harvard University
}

\title{
Changes in the Labor Market for Black Americans, 1948-72
}

THE ECONOMIC STATUS OF BLACK AMERICANS has changed greatly over the past two decades. In some aspects of market position-years of school completed, occupational attainment, and income--blacks have risen relative to whites. Other measures of economic status-employment, unemployment, and labor force participation-reveal marked black-white differences in annual and longer-run patterns of change. Some groups of black workers-women and college-trained men-experienced extraordinary economic advance compared to whites. While black-white differences have not disappeared, the convergence in economic position in the fifties and sixties suggests a virtual collapse in traditional discriminatory patterns in the labor market.

This paper examines the secular and cyclical dimensions of changes in the market for black labor since World War II and seeks to determine the economic and social forces at work. It begins with a broad overview of market developments during this period, highlighting four critical dimensions of change: the secular improvement in the relative income and occupational position of blacks; the more rapid relative advance black women experienced compared with black men; the greater sensitivity, compared with whites, of employment and income of black men to short-

* Jerome Culp did his usual excellent job as research assistant for this paper. I benefited from the comments of Zvi Griliches, Duran Bell, and members of the Brookings panel, among others. 
run changes in gross national product (GNP); and the decline in the labor force participation of prime-age black men. The paper then turns to changes in the ratios of income and employment of blacks to those of whites in more detailed categories, disaggregated by region, education, occupation, and age. ${ }^{1}$ The differential importance of changes in incomes within given groups, shifts in employment across groups, and interactions in the overall advance of blacks are evaluated by "decomposition of change" calculations.

The potential causes of the observed cyclical and secular developments are considered next in the context of the theory of discrimination initially developed by Becker. ${ }^{2}$ This theory directs attention to changes in discrimination that result from changes in its price or cost, which, in the period under study, stemmed from federal and related antidiscriminatory activities that penalized discriminators.

Ensuing empirical analysis of the major postwar development, the relative improvement in black incomes and occupational attainment, focuses on the post-1964 role of governmental and related civil rights activity; on the occupational decisions of black workers in response to improved or existing economic opportunities; and on the characteristics of jobs and workers that led to different rates of advance in different labor markets.

\section{The Traditional Picture}

At the outset, it will be useful to review briefly the traditional picture of black-white differences in the labor market which emerged from a wide variety of studies extending through the $1960 \mathrm{~s}^{3}$ First, blacks had markedly lower incomes than whites, on average and within comparable occupational or educational groups. ${ }^{4}$ In 1959 , for example, the median income of black

1. Reference to these ratios hereafter will be simplified; for example, the ratio of the income of black males to the income of white males will be termed the black-white income ratio for males.

2. Gary S. Becker, The Economics of Discrimination (2d ed., University of Chicago Press, 1971).

3. See, for example, Arthur M. Ross and Herbert Hill, Employment, Race, and Poverty (Harcourt, Brace \& World, 1967); Randall D. Weiss, "The Effect of Education on the Earnings of Blacks and Whites," Review of Economics and Statistics, Vol. 52 (May 1970), pp. 150-59; Alan B. Batchelder, "Decline in the Relative Income of Negro Men," Quarterly Journal of Economics, Vol. 78 (November 1964), pp. 525-48; and Lester C. Thurow, Poverty and Discrimination (Brookings Institution, 1969).

4. In this paper, I use the terms "black" and "nonwhite" in reporting data that actually relate to nonwhites; 90 percent of these are black. Similarly, I compare "blacks" 
males was 58 percent of the median for all men; the comparable figure for black females was 57 percent. Second, the relative income of blacks fell with ascending levels of skill. Among college men, for example, the average income for blacks was 60 percent that for all men, while the ratio for grade school graduates was 75 percent. Third, blacks had considerably less education than whites and, because most were educated in the South during periods of great inequality in the allocation of school resources, education of lower quality as well..$^{5}$ Fourth, blacks were concentrated in low-level jobs, with very few working as managers, professionals, salesmen, ${ }^{\circ}$ or craftsmen. Even when the level (if not quality) of education was similar between the two groups, the black job distribution was not anywhere near so good as the white distribution. Fifth, black unemployment rates were roughly twice as high as the white rates. Finally, the relative position of blacks rose very little over time, except during World War II, when black incomes and job structure improved significantly. ${ }^{6}$

\section{Overview of Change}

The extent to which these patterns of black-white differences were changing in the sixties (and earlier, in some instances) is depicted in Figures 1 and 2. Figure 1 records the relative position of blacks and whites according to variables that reflect permanent labor market status: education, wage and salary income, and an income-weighted index of occupational attainment. ${ }^{7}$ Figure 2 deals with utilization of the black work force. Both figures show significantly different long-run (trend) and short-run (cyclical) changes in the market position of blacks and whites in the postwar years. Figure 1, for example, reveals upward trends in education and in occupational positions; for women through most of the postwar years, and for both sexes after

to the "total" population, of whom 90 percent are white. In some instances, which will be specified, the data do refer to blacks and whites exclusively.

5. Evidence on the quality of education in the South is given by Finis Welch, "BlackWhite Differences in Returns to Schooling" (City University of New York, 1972; processed).

6. The median wage and salary income of black males was 41 percent that of whites in 1939 and 54 percent in 1947. The comparable figures for black women, on the other hand, were 36 percent in 1939 and 34 percent in 1947. The war boom thus benefited black men, but not black women.

7. The income-weighted index is calculated by weighting the proportion of persons in an occupation by 1959 incomes from the 1960 Census. The incomes of total male and female workers are used, respectively. 
Figure 1. Position of Black Workers Relative to White Workers in the Labor Market, According to Selected Characteristics, by Sex, 1947-72

Ratio of

black to white

position
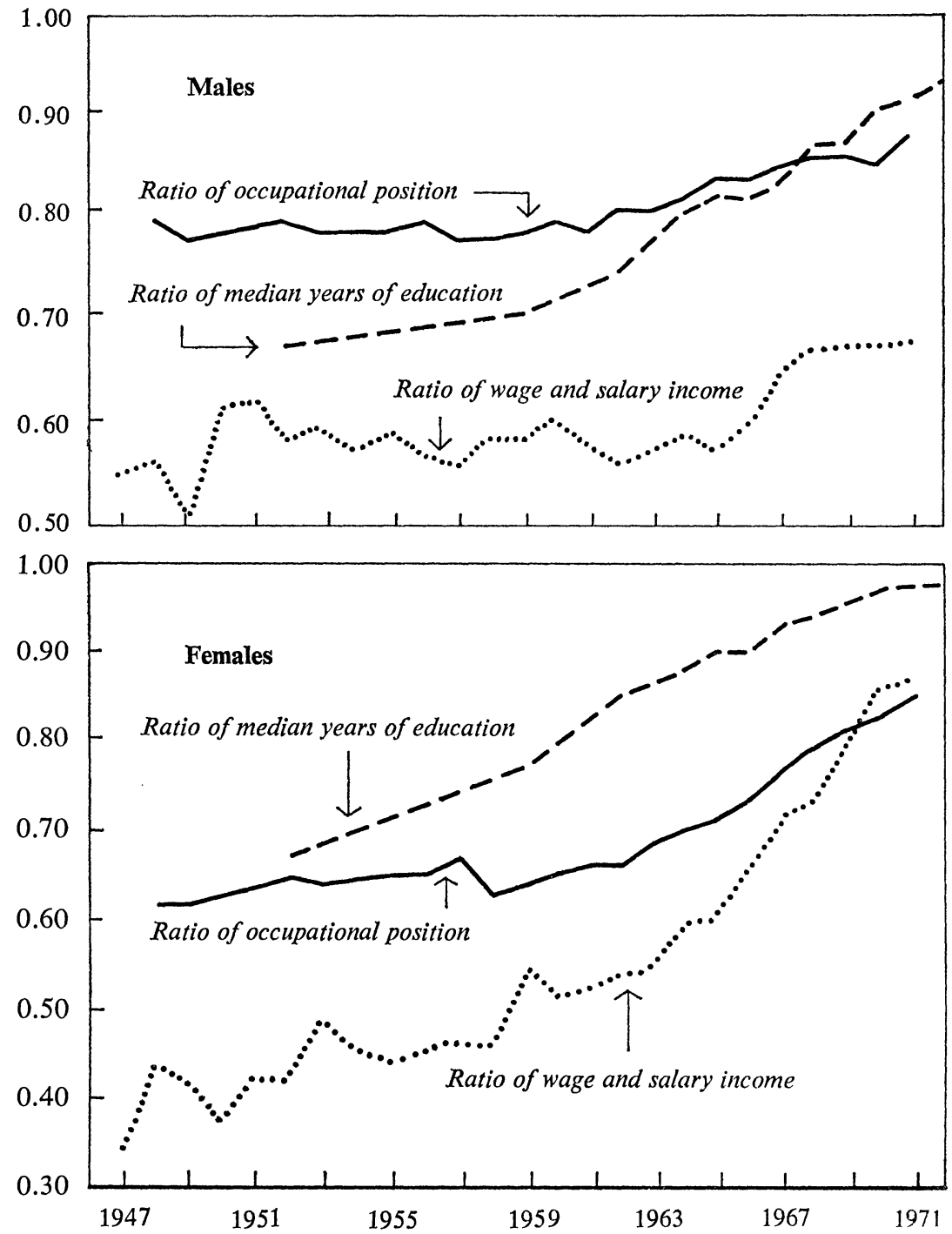

Sources: Median years of education, Manpower Report of the President, 1972, Table B-9, and for 1972, U.S. Bureau of Labor Statistics, "Educational Attainment of Workers, March 1972," Special Labor Force Report 148 (1972; processed), Table 5, p. 40. Wage and salary income, U.S. Bureau of the Census, Current Population Reports, Series P-60, relevant issues. Occupational position, derived from Joe L. Russell, "Changing Patterns in Employment of Nonwhite Workers," Monthly Labor Review, Vol. 89 (May 1966), pp. 503-09;

U.S. Bureau of Labor Statistics, Handbook of Labor Statistics, 1971, Table 19; Employment and Earnings, Vol. 19 (February 1973); and Employment and Economic Status of Negroes in the United States, Staff Report to the Subcommittee on Civil Rights of the Senate Committee on Labor and Public Welfare, 83 Cong. 2 sess. (1954), Table 19. 
Figure 2. Labor Utilization of Black Workers Relative to White Workers, by Sex, 1947-72
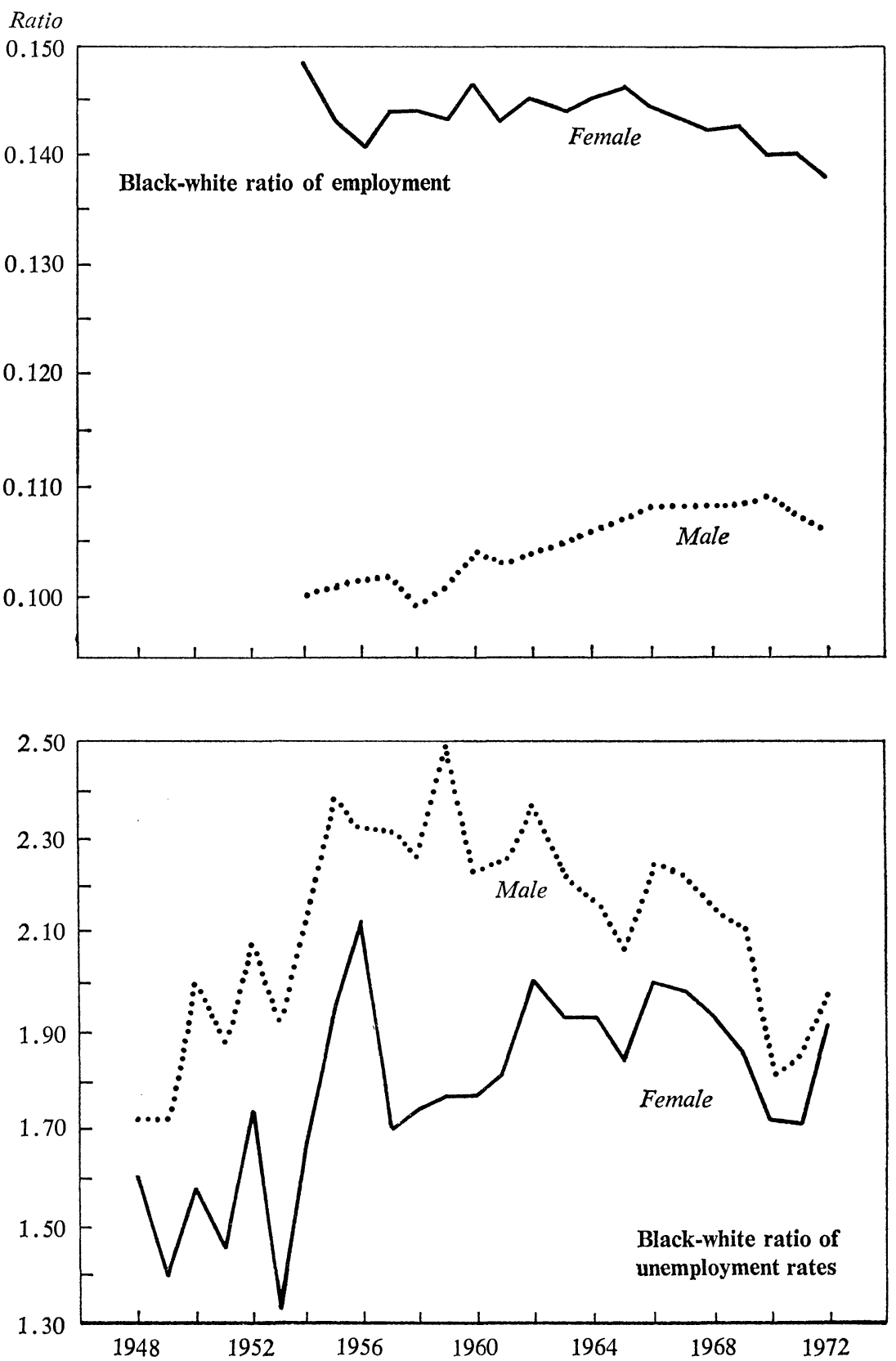

Sources: Manpower Report of the President, 1972, Tables A-10, A-4, and A-16 for employment, labor force participation, and unemployment rates, respectively, and, for 1972 data, Employment and Earnings (February 1973). 


\section{Figure 2 (continued)}

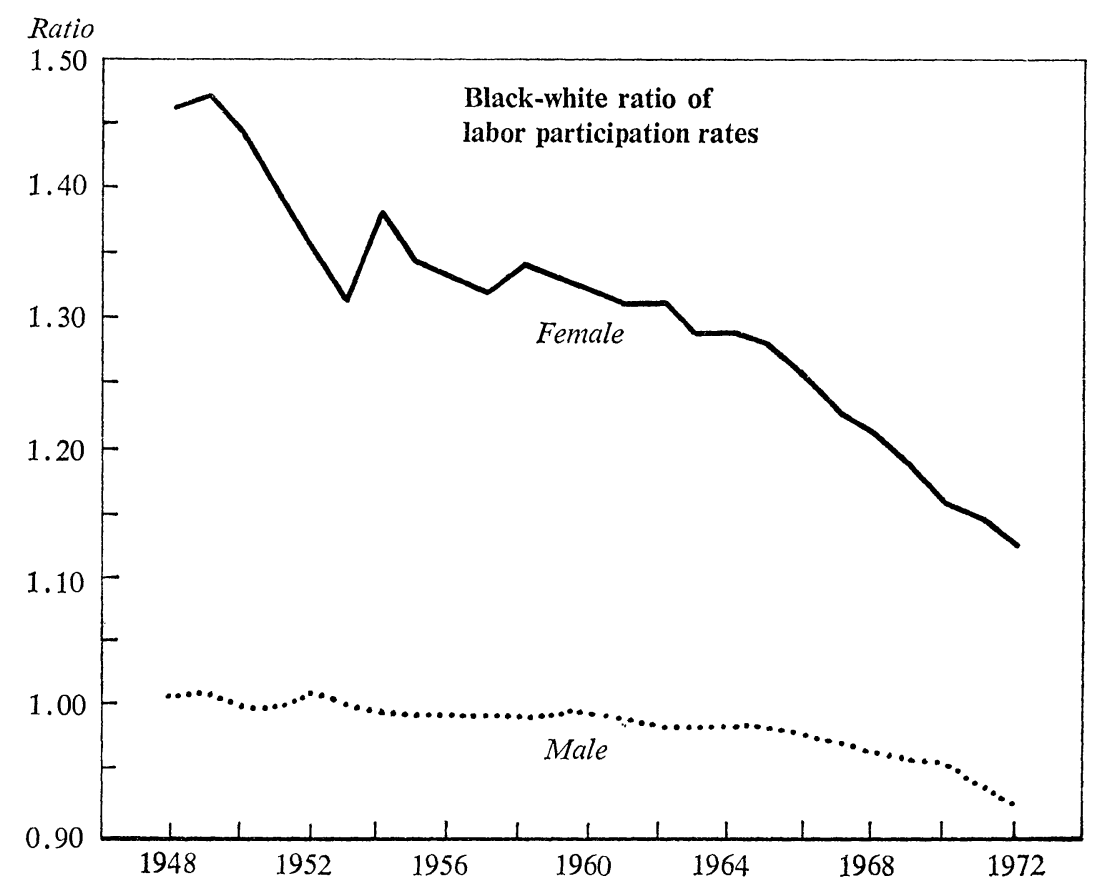

1964, the black-white income ratios increased. There are also noticeable cyclical fluctuations in relative incomes, with the black male position improving, for example, during the Korean war boom and falling in the postKorean recession. Figure 2 shows short-run fluctuations in relative employment for men and labor participation for women. In addition, a downward trend is seen in the black-white labor force participation ratio for both sexes, and a complex pattern of change in relative unemployment rates. The unemployment rate of black males rose in the early 1950s to more than twice the rate for whites and then, starting in 1962, declined to below the 2:1 ratio. The black-white unemployment ratio for females also rose in the early 1950s, but did not trend downward in the 1960s.

\section{FOUR MAJOR CHANGES}

These patterns are examined further in Table 1, where the labor market variables for each race are regressed on a trend variable, time, and a 
measure of cyclical activity, deviation of real GNP from its trend (DGNP). ${ }^{8}$ With the regressions in logarithmic form, the effect of trend or cycle on the relative position of blacks can be determined by subtracting the coefficients of whites from those of blacks. The regressions are designed to summarize the movements in variables over time and, together with the figures, to pinpoint the major dimensions of change since World War II. For a reasonably complete picture of income patterns, three series are used: median wage and salary income, which refers to labor market earnings only; mean total income, which includes other sources but has the advantage of being a mean rather than a median figure; and median income of year-round full-time workers, the best measure of rates of pay. The first two series cover virtually the entire postwar period; the latter is available only since 1955. All of the income series are deflated by the implicit price deflator of gross national product.

The labor force utilization variables used in the computations are the total number of employed persons, the rates of unemployment and of labor force participation, and the participation rate of prime-age men, 35 to 44 years old. Subtracting the participation rate coefficients from the unem. ployment coefficients provides another indicator of utilization, the ratio of unemployed persons to population.

The table and figures reveal four important characteristics of change:

The first is the secular improvement in relative black income and occupational status. The median wage and salary income of black males rose 3.2 percent annually compared with 2.6 percent for whites. Similarly, for occupational indexes, the trend rates of increase were 1.1 percent for black men and 0.6 percent for white men. Even greater relative gains were made by black women - 4.9 percent annual trend in income compared with 1.7 percent for whites and 1.9 versus 0.5 percent in occupational status. Blacks

8. More precisely, the log of real GNP (RGNP) was regressed on time $(t)$ for the period 1947-72 with the following result:

$$
\begin{gathered}
R G N P=7.95+0.037 t . \\
(0.015)(0.001) \\
R^{2}=0.99 ; \text { standard error of estimate }=0.033 .
\end{gathered}
$$

The numbers in parentheses are standard errors. Deviations from the regression line are used to measure short-run fluctuations. The deviation variable is, it should be noted, highly correlated with the deviation of GNP from potential GNP $(r=0.98)$ and is thus comparable to this cyclic measure. Alternative measures of cyclical conditions-deviation of GNP from potential GNP and from the trend level of money GNP, and unemployment-yield results similar to those in the table. 


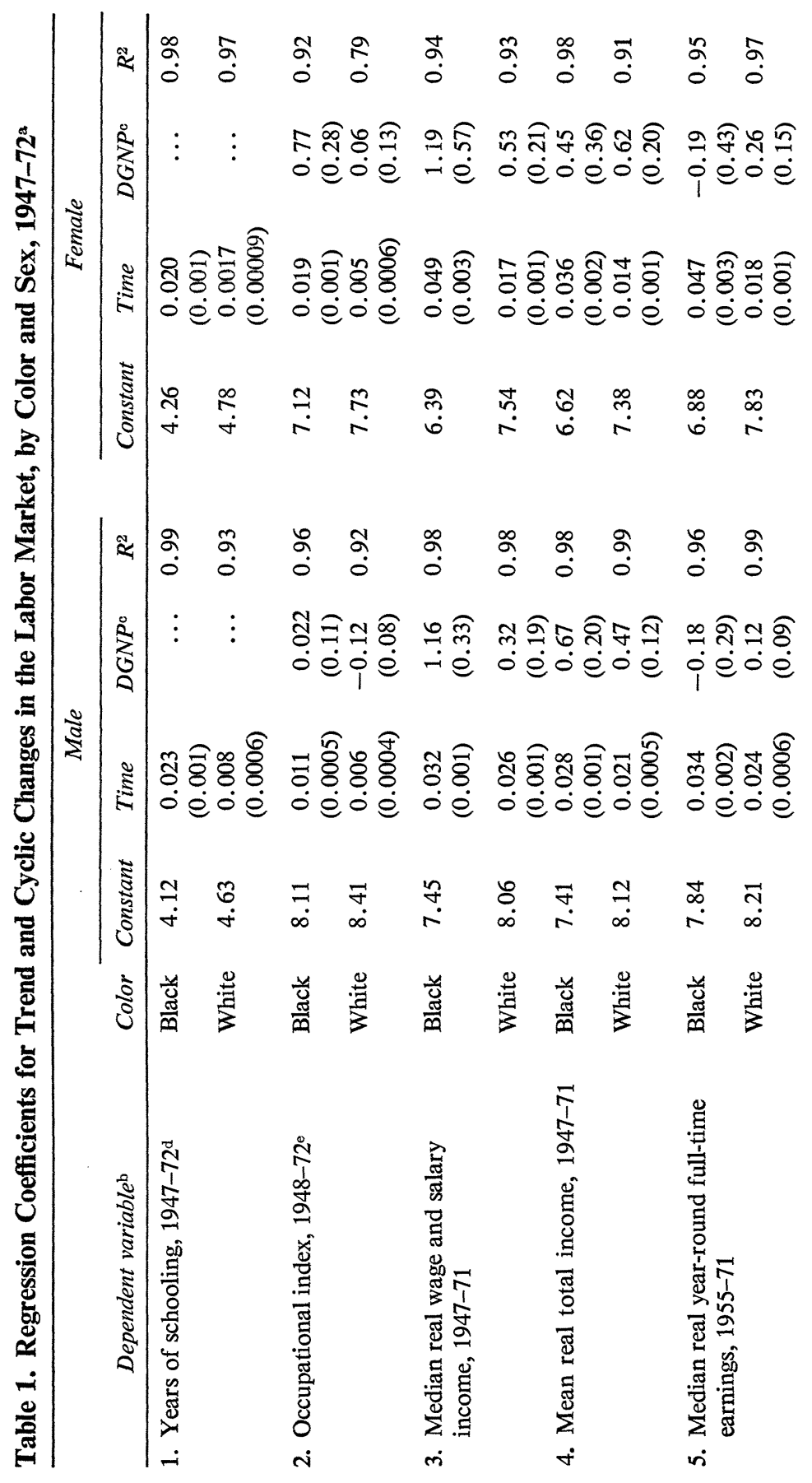




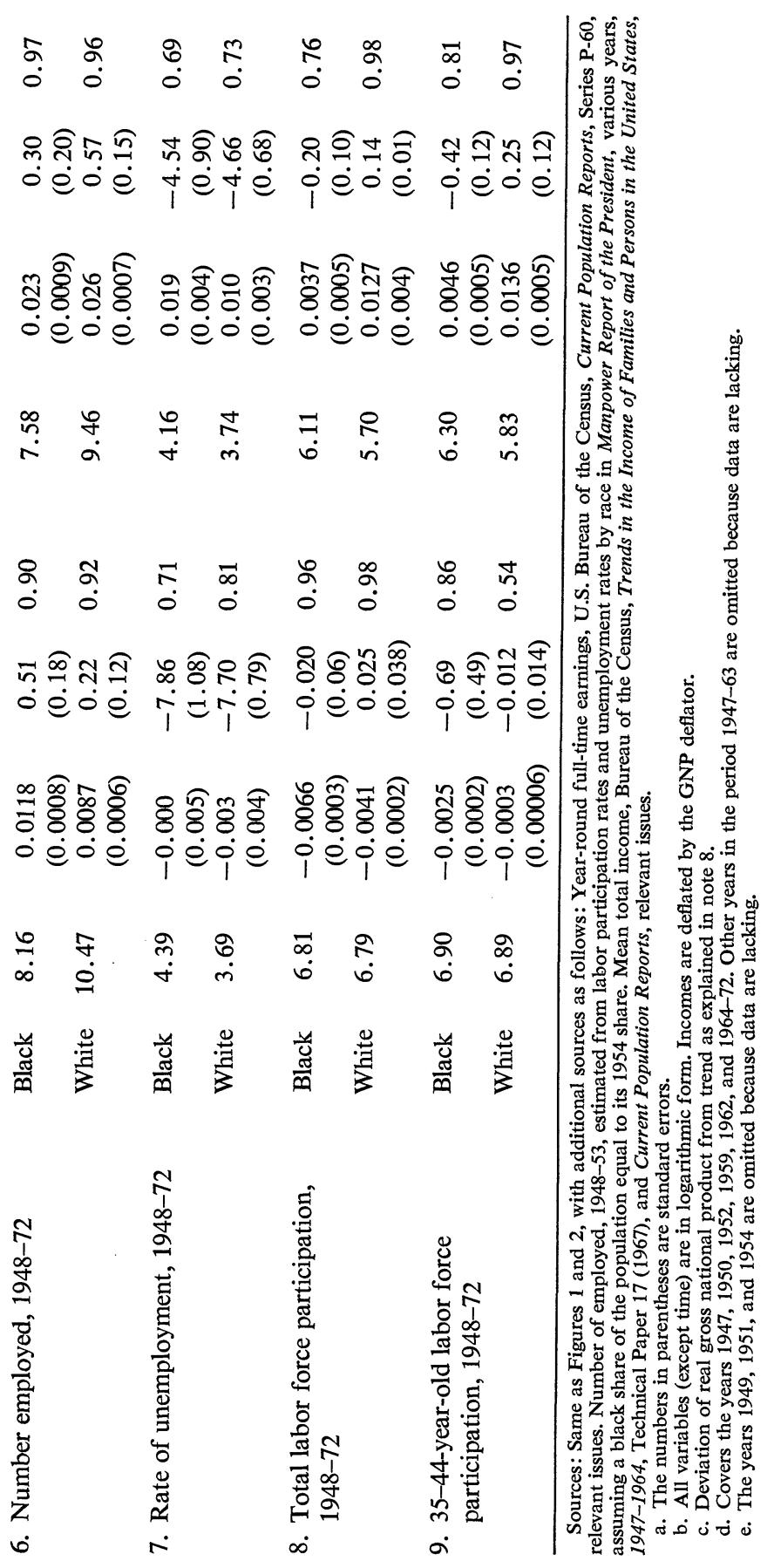


also achieved relative gains in mean total income and even larger ones in year-round full-time incomes, suggesting that differentials in wage rates shrank more rapidly than total income differentials. Underlying these trends is the rapid decline in the educational gap between blacks and whites indicated in the coefficients of time $(t)$ for the years-of-schooling equations in Table 1. Unlike the trend in schooling, however, the increase in income and occupational position occurred unevenly over time, accelerating in the late 1960s following passage of the Civil Rights Act of 1964. According to Figure 1, black-white income ratios for females, which began rising in the 1950s, increased sharply in the 1965-71 period, while the ratio for males moved up little until that period. These patterns, which are not caught in the simple regressions on time and deviations of GNP from its trend, are dealt with in the analysis below of the effect of civil rights activity.

Second, a markedly greater improvement in the economic position of black females than in that of males is evident in the table. In all of the calculations for income and occupational status (lines 2-5), the coefficients on time are much larger for black women than for black men; moreover, differences in black-white coefficients show larger relative gains for the women. In the early 1950s, black women were further behind white women than black men were behind white men; by 1972, their relative income exceeded, and their relative occupational position equaled that of black men. Note, however, that the extraordinary improvement in the black-white income ratio for females is as much the result of a slow increase in the incomes of white females (evident in all the data, including those for yearround full-time workers) as a rapid increase in the incomes of black women. The especially favorable trends for black women have potential implications for such sociological phenomena as the increased proportion of female-led black families.

Third, cyclical changes in the income and employment of black men are found to be more sensitive to short-run fluctuations in GNP than are those of white men. The coefficients on $D G N P$ for wage and salary income (line 3), total income (line 4), and employment (line 6) are larger for black men, often by sizable amounts. But that racial pattern is not found in earnings of year-round full-time workers (line 5) over the cycle, indicating that greater changes in employment and hours worked by blacks are the primary cause of their greater income variability.

A different pattern of unemployment relationships over the cycle is shown in line 7 , with unemployment rates of both races having virtually the same 
proportionate response to short-run deviations of GNP from trend. But that implies, of course, that when the economy weakens, the unemployment rate of blacks - always higher than that of whites-rises by a larger number of percentage points and results in a larger relative decline in employment. ${ }^{9}$ These results thus corroborate those for employment, supporting the widely asserted last in, first out pattern of black employment over the cycle. Some investigators have mistakenly interpreted the cyclical insensitivity of the ratio of unemployment of black men to that of whites as evidence that the position of black men in the labor market is not especially vulnerable to cyclical declines. ${ }^{10}$

The table also reveals differences in the effect of cyclical changes in GNP on black and white women, with the wage and salary income of the former being more responsive to $D G N P$ than that of the latter (line 3 ) but with total mean income, year-round earnings, and employment less responsive. Consistent with the greater cyclical variation in employment of white than black females is the tendency for black women to increase their labor force participation in recessions and to decrease it in prosperous times, in sharp contrast with the behavior of white women (lines 8 and 9). ${ }^{11}$ Black women apparently are the only major group of workers who respond to a weak job market by supplying additional job seekers, perhaps because of the marked changes in employment for black male breadwinners over the cycle.

Fourth, in contrast with the general secular advance of blacks is the decline in labor force participation rates relative to those of whites shown in Figure 2 and lines 8 and 9 of Table 1. While the direction of the trend is the same for men and women, the underlying behavior differs greatly. The major factor operating to change the relative male participation rates is a sharp drop in participation by black males, while among females the trend

9. Consider two populations of 10 persons, one with 10 percent unemployed $(W)$ and the second with 20 percent $(B)$. A change in GNP that increases both unemployment rates by the same proportion-say, a doubling-necessarily reduces employment in $B$ by proportionately more than in $W(-25$ percent against -11 percent).

10. Most notably Harry J. Gilman, in his papers, "Economic Discrimination and Unemployment," American Economic Review, Vol. 55 (December 1965), pp. 1077-96, and "The White/Non-white Unemployment Differential," in Mark Perlman (ed.), Human Resources in The Urban Economy (Johns Hopkins Press for Resources for the Future, 1963).

11. This has also been pointed out by Jacob Mincer, among others, in "Labor-Force Participation and Unemployment: A Review of Recent Evidence," in Robert Aaron Gordon and Margaret S. Gordon (eds.), Prosperity and Unemployment (John Wiley, 1966). 
stems from the rise in white participation rates. In the former case, initially similar behavior diverges over time; in the latter, dissimilar behavior converges. The data on men aged 35-44 years show, moreover, that the decline in black male participation is not merely a "teenage" phenomenon. Between 1960 and 1971 black men in both the 35-44 and the 45-54 age groups reduced their participation significantly; the rate for the first group fell from 95.5 to 92.0 and that for the second dropped from 92.3 to 86.9 , while white participation rates declined only slightly. This important development and its relation to the overall improvement in the black position presents a major puzzle that I intend to study in the future.

\section{Changes in Incomes, by Labor Market}

Underlying the changes in average incomes reported in Figure 1 and Table 1 are changes in the incomes and distribution of employment of blacks and whites in specific labor markets disaggregated according to other, narrower, criteria. To what extent has the relative income of black workers increased within detailed regional, educational, and occupational labor markets, as well as on the average? Does the pattern of change differ across labor markets?

Table 2 summarizes income data pertaining to these questions for selected years. Given varying availability of data and the desire to cover as lengthy a postwar period as possible, different triplets of years are used: 1953, 1959, and 1971 for the regional breakdown; 1949, 1959, and 1971 for education; and 1949, 1959, and 1969 for occupation. The table records median income for nonwhites expressed as a percentage of white or total medians and, where the data were available, the income of year-round full-time workers as well. Since 1953 and 1969 had especially tight labor markets, while 1949, 1959, and 1971 all had unusually high unemployment rates (5 to 6 percent), the calculations are affected by cyclical differences. But a number of checks I performed suggested that those cyclical influences are relatively small in the overall pattern. ${ }^{12}$

12. Three cyclical checks were made. First, I computed income ratios for years with similar unemployment rates. In the regional data I replaced 1953 figures with ones for 1954 (the unemployment rate was then 5.5 percent). As would be expected, the regional ratios were pulled down 2 to 3 percentage points in most cases. The exception was men in the West; in that case, the data show extraordinarily low income for nonwhites in 
The most important finding in Table 2 is the tendency for the income ratios of nearly all subgroups to improve for blacks in the postwar period, especially in the 1960s. Among men, increases in the black-white income ratio occurred in all regions except the Northeast, where the in-migration of less educated blacks caused differences in years of schooling between blacks and whites to widen and may, other things equal, have held down the income ratio. The largest relative advance shown in the data is for black college men, the rapid increase in whose income had, by 1971, broken the historic pattern of decline in black-white income ratios as education lengthened. ${ }^{13}$ In addition, relative incomes for black males rose in most occupations during the sixties and also increased significantly among managers and professionals in the fifties. ${ }^{14}$

The differential regional pattern in black-white income ratios for males can be examined further with decennial census data for 1959 and 1969. These data confirm the large increase in the income ratios in the South shown by the CPS and also indicate somewhat greater improvements in the North and West than is evident in the CPS data. According to the Census of Population, the black-white income ratio for men aged 25-64 in the South increased from 49 to 58 percent while that of nonsouthern men 25-64 years old rose from 66 to 73 percent. Black college graduates in the North and West enjoyed an exceptional gain in relative income of 10 percentage points (from 67 percent to 77 percent) and workers $25-34$ years old a gain of 17 points (from 71 to 88 percent). These improvements, however, still left considerable black-white income gaps for most male workers even in the least discriminatory regions of the country.

Among females, the black-white income ratio rose strongly in both

1954. I am convinced that this must be an aberration of the data, which are based on the relatively small samples of the Current Population Survey (CPS). A second check was made by regressing regional incomes on time and the deviation of real GNP from trend; those calculations confirm the pattern in the table. Third, to check the importance of cyclical influences on black-white income ratios for occupations, I calculated the ratios for men in 1971 from the CPS data and found them to be similar to those for 1969 from the Census shown in Table 2. I was unable to use CPS data for women because these record incomes in the job held longest while Census figures deal with total incomes; the difference in definition has a major effect on female incomes by occupation.

13. The historic pattern is cited in Richard B. Freeman, Labor Economics (PrenticeHall, 1972), p. 89, and Weiss "Effect of Education," among others.

14. The effect of the increase in the fifties in professional and managerial incomes on the occupational decisions of black college men is examined in Richard B. Freeman, Black Elite Educational Discrimination (McGraw-Hill, forthcoming). 


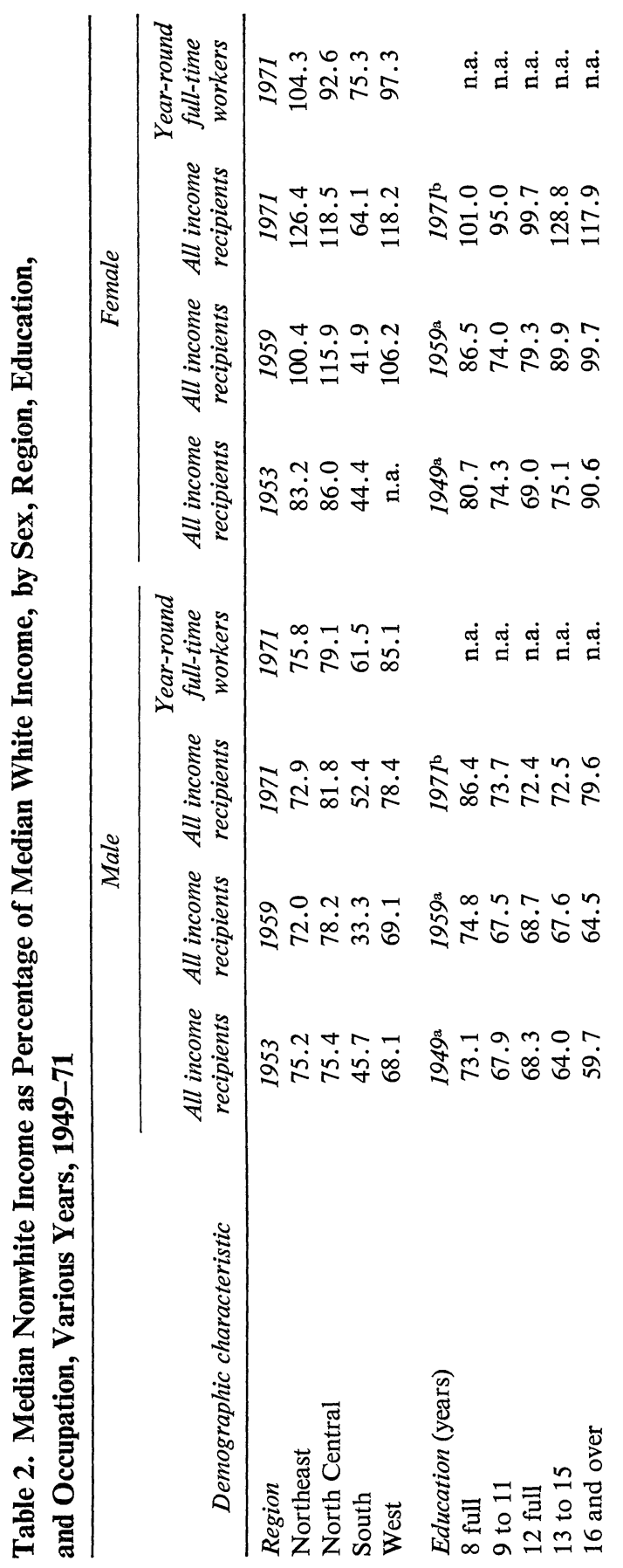




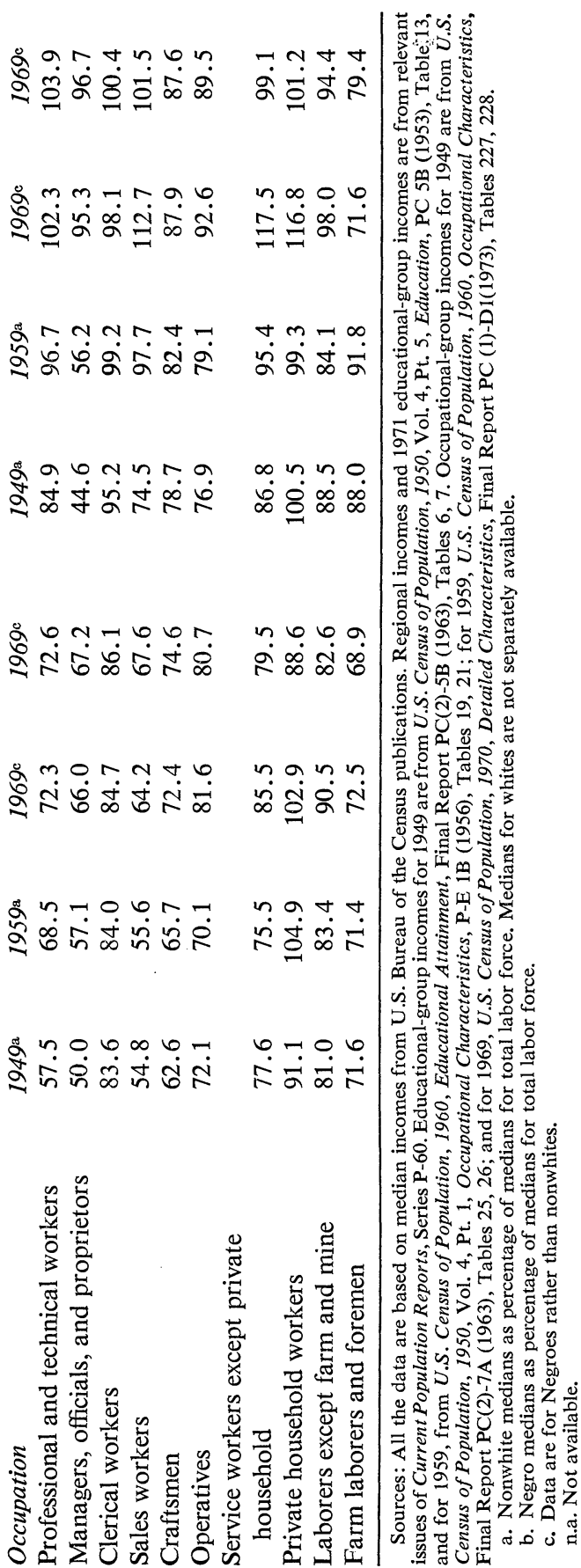


decades in most categories with the consequence that virtual equality in incomes was attained by the end of the sixties. In 1971, the ratio of incomes for grade school women was, for example, 1.01 and that for high school graduates 0.997 . The income ratios for year-round full-time workers indicate that the similarity between black and white incomes within specific labor markets did not arise simply because black women work more than whites over the year. All told, the evidence points to an absence of market discrimination against black women workers by the end of the decade, except possibly in the South. And much of the southern differential, it should be noted, is associated with differences in years of schooling: In 1970 median educational attainment for black southern women was 9.0 years compared with 11.9 years for their white counterparts.

\section{AGE-INCOME PATTERNS}

Black-white income differentials have, according to most studies, an important age component. The black age-earnings profile is less steep than that of whites, suggesting in the human capital framework of analysis that blacks invest less in on-the-job training than whites, possibly because of discrimination in training opportunities. ${ }^{15}$ The pattern of income differentials by age and education for 1949, 1959, and 1969 is examined in Table 3, which can be read in several ways: Horizontally, the data show income differentials for given age groups; diagonally, the experience of a cohort over time can be pursued (for example, the group aged 25-34 in 1949 became 35-44 in 1959 and 45-54 in 1969); vertically, the cross-sectional age-earnings profile is visible. To preserve comparability between the mean incomes for 1969 and the medians for 1949, ratios using both medians and means are recorded for men in 1959; the ratios are similar save for older high school and college graduates, among whom black men do relatively worse in the mean figures. Because little difference exists between median and mean incomes for women, it is legitimate to compare the 1969 means to the 1959 medians, despite the lack of an overlapping series.

15. Morton Zeman first pointed out the significance of the age component in "A Quantitative Analysis of White-Nonwhite Income Differentials in the United States" (Ph.D. thesis, University of Chicago, 1955). Also, see Robert E. Hall, "Wages, Income and Hours of Work in the U.S. Labor Force," in Glen G. Cain and Harold W. Watts (eds.), Labor Supply and Income Maintenance (forthcoming). The interpretation of the racial difference in age-earnings profiles that relies on the differences in investment in training pervades much of the human capital literature on discrimination. 
Table 3. Average Nonwhite Income as Percentage of Average Income, by Age, Education, and Sex, 1949, 1959, and 1969

\begin{tabular}{|c|c|c|c|c|c|c|c|}
\hline \multirow[b]{3}{*}{$\begin{array}{l}\text { Education } \\
\text { and age }\end{array}$} & \multicolumn{4}{|c|}{ Male } & \multirow{2}{*}{\multicolumn{3}{|c|}{ Female }} \\
\hline & \multirow[b]{2}{*}{$\begin{array}{l}1949, \\
\text { using } \\
\text { median }\end{array}$} & \multicolumn{2}{|c|}{1959} & \multirow[b]{2}{*}{$\begin{array}{l}1969, \\
\text { using } \\
\text { mean }\end{array}$} & & & \\
\hline & & $\begin{array}{l}\text { Using } \\
\text { median }\end{array}$ & $\begin{array}{l}\text { Using } \\
\text { mean }^{\mathrm{a}}\end{array}$ & & $\begin{array}{l}1949, \\
\text { using } \\
\text { median }\end{array}$ & $\begin{array}{l}1959, \\
\text { using } \\
\text { median }\end{array}$ & $\begin{array}{l}1969 \\
\text { using } \\
\text { mean }\end{array}$ \\
\hline \multicolumn{8}{|c|}{ All levels of education } \\
\hline $18-24$ & 70 & 70 & 67 & 85 & 46 & 55 & 92 \\
\hline $25-34$ & 59 & 61 & 61 & 70 & 56 & 70 & 95 \\
\hline $35-44$ & 55 & 59 & 57 & 64 & 55 & 65 & 91 \\
\hline $45-54$ & 54 & 55 & 52 & 58 & 49 & 46 & 76 \\
\hline $55-64$ & 49 & 52 & 51 & 54 & 49 & 52 & 69 \\
\hline \multicolumn{8}{|c|}{ Grade school graduates } \\
\hline $18-24$ & 74 & 70 & 71 & 72 & 62 & 78 & 90 \\
\hline $25-34$ & 73 & 68 & 71 & 74 & 72 & 72 & 93 \\
\hline $35-44$ & 67 & 72 & 73 & 72 & 68 & 72 & 86 \\
\hline $45-54$ & 70 & 71 & 70 & 74 & 64 & 61 & 81 \\
\hline $55-64$ & 69 & 68 & 69 & 73 & 73 & 68 & 77 \\
\hline \multicolumn{8}{|c|}{ High school graduates } \\
\hline $18-24$ & 74 & 68 & 73 & 87 & 52 & 57 & 95 \\
\hline $25-34$ & 72 & 70 & 69 & 76 & 67 & 78 & 103 \\
\hline $35-44$ & 67 & 72 & 71 & 71 & 70 & 84 & 102 \\
\hline $45-54$ & 63 & 68 & 62 & 70 & 62 & 68 & 92 \\
\hline $55-64$ & 63 & 67 & 57 & 66 & 66 & 61 & 80 \\
\hline \multicolumn{8}{|c|}{ College graduates, 4 years or more } \\
\hline $18-24$ & 81 & 76 & 80 & 98 & 90 & 91 & 97 \\
\hline $25-34$ & 64 & 68 & 67 & 78 & 93 & 107 & 114 \\
\hline $35-44$ & 59 & 62 & 59 & 71 & 94 & 109 & 118 \\
\hline $45-54$ & 56 & 58 & 49 & 65 & 85 & 91 & 106 \\
\hline $55-64$ & 52 & 56 & 45 & 57 & 81 & 82 & 91 \\
\hline
\end{tabular}

Sources: 1949, 1959, same as Table 2; 1969, U.S. Census of Population: 1970, Detailed Characteristics, Table 249.

a. Since median earnings in 1969 were not available, mean earnings are shown. This results in a small bias against nonwhites in 1969.

Four important findings emerge from the table. First, like the results of other studies, the cross-sectional age-earnings ratios show that younger blacks do better than older blacks relative to whites, on average and at given educational levels. Among males, income ratios decline fairly continuously by age, except for grade school graduates. Among females the ratios drop for those aged 45 and over.

Second, read horizontally, the data for men reveal that the various age 
groups have dissimilar increases over time in income ratios, with the young generally improving more than older workers. In the 1960s, the black-white income ratio for males rises, for example, by 18 points for 18-24-year-olds and by 9 points for 25-34-year-olds, but by only 5 or so points for men over 35. Among women, sizable increases in income ratios occurred for 18-24-, 25-34-, and 35-44-year-olds from 1949 to 1959 and for all groups from 1959 to 1969 . In the latter decade, the ratio for women 25-34 years old jumped by 25 points, that for the 35-44-year group by 26 points, and that for 45-54-year-old workers by 30 points. Over the entire period, the gain in the income ratios for females ranges from 46 percentage points for the youngest age group to 20 points for the oldest.

Third, educational attainment makes a difference in both the level of and the change in income ratios. Young college-trained men experienced the largest increase in income ratios in the 1960s, followed by high school graduates and then by grade school graduates. These data highlight the significant change in the incentive for young black men to pursue higher education. The pattern among women is different, in large measure because the better educated were already earning as much as, or more than, their white equivalents in 1959. In this case, the less educated groups show greater improvement in income ratios.

Fourth, and most important, the progress of a cohort over its life cycle through time differs greatly from the cross-sectional patterns. Taking all educational groups together, black men aged 25-34 in 1949, for example, had a median income that was 59 percent that of whites in 1949 and 1959, and about the same relative mean income in 1959 and 1969. Similarly, male high school graduates aged 25-34 in 1949 maintained a comparable position to whites in 1959 and 1969. Data for the analogous college cohort indicate some improvement in the 1960s, though it should be noted that older nonwhite college graduates include relatively many nonblacks, especially Orientals. Interestingly, among college graduates the ratio of the income of Negroes to that of all male workers exceeds the total nonwhite ratios (recorded in the table) among the youngest workers (1.06 for those aged $18-24$ ) but is markedly lower for older workers ( 0.58 for the 45-54 group). The next oldest cohort (35-44-year-olds in 1949) shows a greater advance in relative incomes in the 1960s, with an overall increase in the income ratio of 2 percentage points and a gain of 3,4 , and 8 points in the various educational categories.

A more striking pattern of relative advances for older men, concentrated 
in the post-1964 period, is found in social security earnings data by Vroman. His figures show increases on the order of 7 to 8 percentage points from 1964 to 1969 for older black men grouped in five-year age intervals, with all cohorts advancing. ${ }^{16}$ There thus appears to have been some improvement in the relative income of older black men in the 1960s, though the extent of advance was far less than that for younger men or for black women.

The stability of the relative income of black male cohorts in the 1950s, when discriminatory differences were roughly unchanged, suggests that, contrary to the implication of the cross-sectional data, black and white investments in on-the-job training are roughly similar. If blacks invested less in job training and discrimination was fixed, cohort income ratios would have declined from 1949 to 1959, which they did not. With similar on-thejob investments in training, the cross-sectional patterns in Table 3 are probably best interpreted in terms of the differential productivity of the age groups, with older blacks further behind whites as a result of less schooling, and a lower quality of education and human capital due to factors unrelated to the job market.

The smaller gains in the 1960s in income ratios of older male cohorts compared with those of females and young males further imply that the economic position of older men is less sensitive to market developments than that of other workers. This is presumably because of the difficulty that older black men have in taking advantage of new market opportunities requiring occupational mobility and investments in skills. The 50-year-old black laborer, for example, could not switch into construction craft work despite the new opportunity open to black men. If black and white men have, in fact, similar age-earnings trajectories, the cross-sectional patterns in Table 3 are probably best interpreted in terms of the differential productivity of the age groups, with older blacks further behind whites as a result of less schooling, and of lower-quality education and related training.

The differences in the age-earnings patterns in the cross-sectional and cohort data are even more striking for women. In this case the income ratios not only fail to decline as a cohort ages, but indeed rise sharply. The cohort aged 25-34 in 1949, for example, had a relative income ratio of 0.56 in 1949 , of 0.65 in 1959, and of 0.76 in 1969. This pattern is yet another indi-

16. W. Vroman, "Changes in Black Workers' Relative Earnings: Evidence from the 1960's” (Office of Economic Opportunity, April 1973; processed). 
cation of differences in the labor market for black men and women. Two factors appear to account for the improved status of black female cohorts. One is the greater investment in job skills compared with white women, due to firmer commitment to work. The other is the nature of many jobs for women, such as clerical and factory operative work, which do not have steep age-earnings profiles nor require lengthy training and which thus enable older black women to be upwardly mobile in a period of improved opportunities without extensive investments in training.

In sum, the evidence in Table 3 suggests that the gains of cohorts have been relatively permanent in past decades. For the future, it implies that, barring an intensification of discrimination, young blacks are likely to retain current gains in relative income, and not lose them as they age.

\section{OCCUPATIONAL EMPLOYMENT PATTERNS}

The relative number of black Americans in various job markets, as well as their relative incomes, changed greatly in the postwar period. Large numbers of blacks migrated to the North, obtained additional education, and advanced in the job structure. Table 4 examines, for the major occupational groups, the changed occupational distribution of blacks over time and over the business cycle with simple regressions of the black "penetration ratio"- the proportion of blacks in an occupation-on time and on the deviation of GNP from its trend level. The trend coefficients show sizable increases in the relative number of black men in professional, managerial, craft, clerical, and operative jobs, and a corresponding reduction in the number of black farmers and farm workers. Among women, the principal secular change is the shift from domestic services and farming to clerical, factory operative, and professional employment. Underlying the simple trend coefficients are differential changes in black occupational employment by time period. Among men, the relative number of black professionals and craftsmen began increasing in the late 1950s and early 1960s, while the relative number of managers did not trend upward until the late 1960s: Between 1964 and 1972 the percentage of male managers who were black jumped from 2.1 to 3.5 percent. Among women, the relative number of black clerical and operative workers also expanded rapidly in the late 1960s, while the proportion of professionals began to rise earlier.

Any one or a combination of three factors could underlie the cyclical ups and downs of black employment uncovered earlier. Blacks could be con- 
centrated in low-skill, cyclically sensitive jobs, for reasons of low education or discrimination in employment, and experience the same fluctuations in work as whites holding the same types of jobs. Second, blacks could differ from whites in the same occupation in characteristics such as education, specific on-the-job training, or age that produce potential differences in short-run demand relations. Finally, as I shall demonstrate below, if discrimination attaches a fixed nonpecuniary cost to hiring blacks, which is roughly invariant over the cycle, it could cause the greater cyclical swings within job markets that blacks experience. While not conclusive due to the level of aggregation and the absence of data on worker characteristics, the computations reported in Table 4 show that the last in, first out phenomenon is characteristic of several important occupations and thus not solely the result of distribution of blacks among jobs. The cyclical coefficients are significantly different from zero among male factory operatives and craftsmen and female service workers, and are positive in the vast majority of cases; only the category of female farm laborers (which is relatively small) records a significant negative sign on the cyclical term.

\section{DECOMPOSITION OF INCOME CHANGES}

Changes in income and employment can be fruitfully examined in the context of a simple accounting scheme that decomposes them into potentially meaningful components. Since average income is a weighted sum of subgroup incomes, the percentage changes relevant for comparison of relative incomes can be decomposed as follows:

$$
\dot{w}=\Sigma \gamma_{i} \dot{w}_{i}+\Sigma \gamma_{i} \dot{\alpha}_{i}+\Sigma \gamma_{i} \dot{\alpha}_{i} \dot{w}_{i},
$$

where

$w=$ average income

$w_{i}=$ average income in occupation $i$

$\alpha_{i}=$ proportion of persons in occupation $i$

$\gamma_{i}=\left(\alpha_{i} w_{i}\right) / w$, the proportion of income earned in the occupation;

dots above variables refer to relative changes (that is, $\dot{w}=\Delta w / w$ ). The first term in equation (1) measures the effect of changes in subgroup incomes $\left(\dot{w}_{i}\right)$ with all else fixed. The second term reflects changes in the distribution of persons among subgroups $\left(\dot{\alpha}_{i}\right)$ at base wage rates; it is positive when the proportion in high-wage categories $\left(w_{i}>w\right)$ grows, on average. The last 


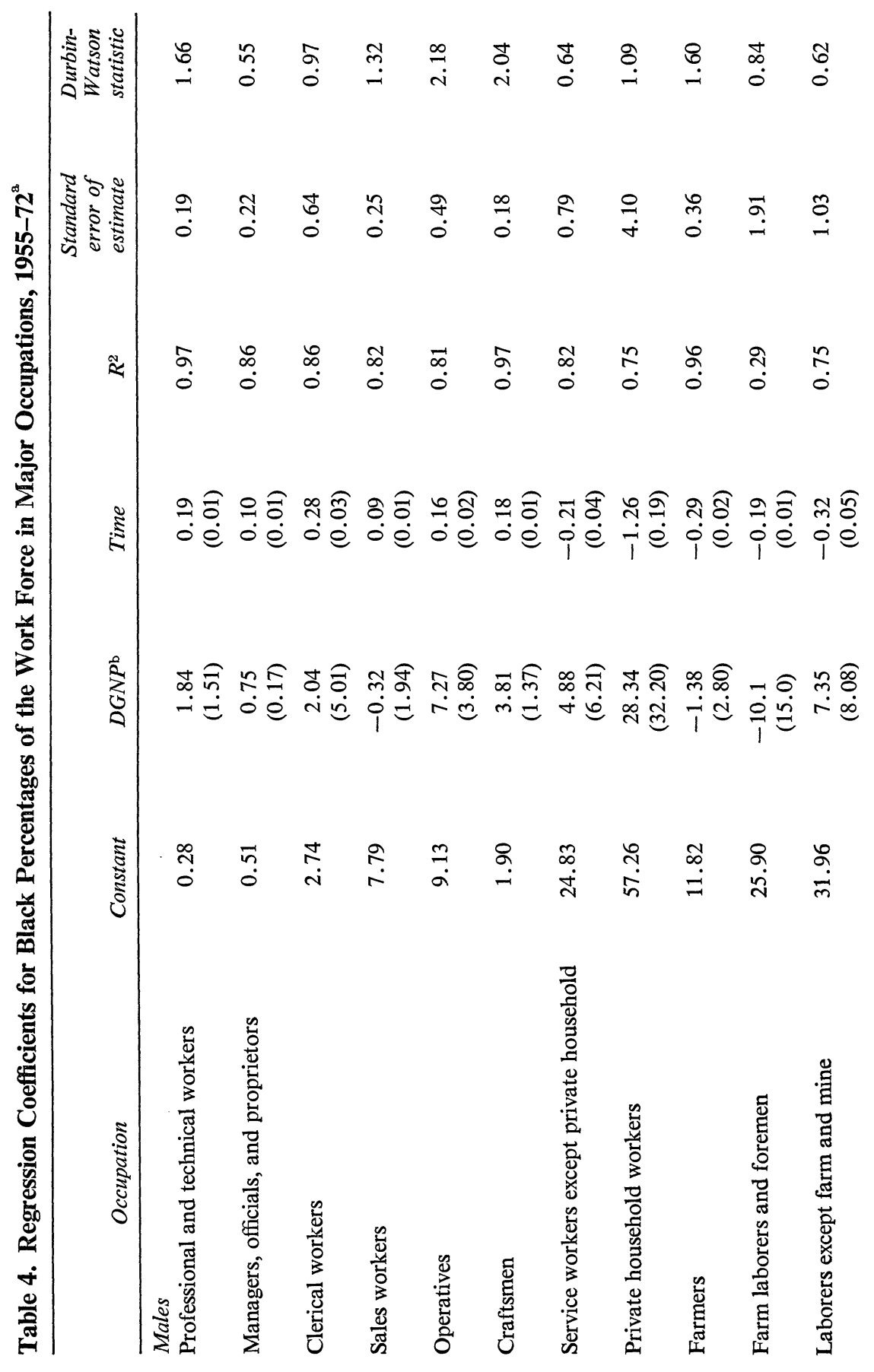




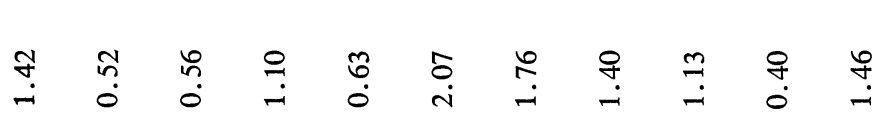

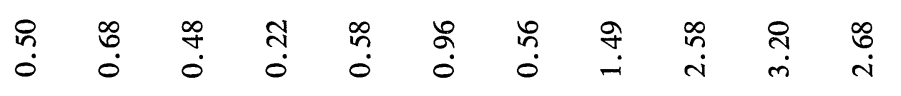

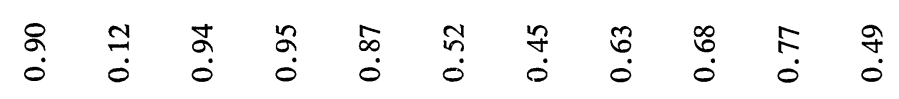

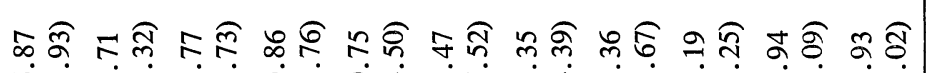

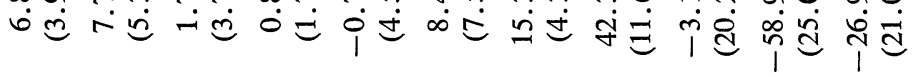

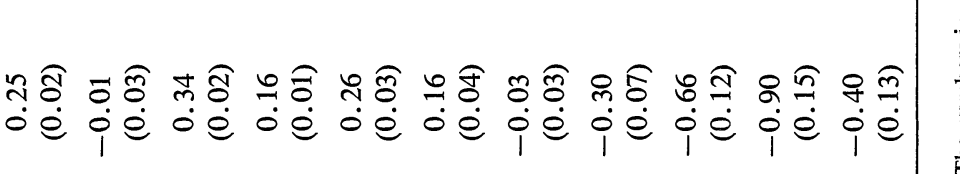


term is the interaction between income changes and distributional changes and is positive when they are positively correlated.

While not a theory of behavior, the decomposition equation can provide important clues to the economic forces underlying observed changes: Significant positive interaction terms, for example, suggest important supply response effects, as a positive correlation would occur when employment and wages moved along a supply curve, in response to shifts in demand. The subgroup distribution term $\left(\Sigma \gamma_{i}{ }_{i}\right)$ might also be interpreted as the result of lagged adjustments of supply to wage differentials. A separate analysis of supply and demand relations is needed to evaluate such clues and compare alternative explanatory hypotheses.

Table 5 decomposes changes in the real incomes of blacks and whites using regional, educational, and occupational subgroups. Each of the numbers in the table gives the percentage increment in income due to the decomposition components and the total increment over the period, with

Table 5. Decomposition of Changes in Real Incomes, for Black and White Males and Females, by Education, Occupation, and Region, 1949-71

\begin{tabular}{|c|c|c|c|c|}
\hline \multirow[b]{2}{*}{$\begin{array}{l}\text { Demographic characteristic, } \\
\text { period, color, and sex }\end{array}$} & \multicolumn{4}{|c|}{ Ratio of decomposition components to base incomes } \\
\hline & $\begin{array}{c}\text { Change in } \\
\text { wages } \\
A\end{array}$ & $\begin{array}{c}\text { Change in } \\
\text { distribution } \\
B\end{array}$ & $\begin{array}{l}\text { Interaction } \\
\quad C\end{array}$ & Total \\
\hline \multicolumn{5}{|l|}{ Education, 1949-71 } \\
\hline White, male & 0.43 & 0.17 & 0.17 & 0.77 \\
\hline Black, male & 0.52 & 0.21 & 0.22 & 0.95 \\
\hline White, female & 0.29 & 0.19 & 0.08 & 0.56 \\
\hline Black, female & 0.68 & 0.30 & 0.34 & 1.32 \\
\hline \multicolumn{5}{|l|}{ Occupation, 1949-69 } \\
\hline White, male & 0.66 & 0.10 & 0.05 & 0.81 \\
\hline Black, male & 0.76 & 0.23 & 0.19 & 1.18 \\
\hline White, female & 0.39 & 0.08 & 0.03 & 0.50 \\
\hline Black, female & 0.63 & 0.39 & 0.26 & 1.28 \\
\hline \multicolumn{5}{|l|}{ Region, 1953-71 } \\
\hline White, male & 0.43 & 0.00 & 0.00 & 0.43 \\
\hline Black, male & 0.62 & 0.12 & 0.02 & 0.76 \\
\hline White, female & 0.28 & -0.01 & 0.00 & 0.27 \\
\hline Black, female & 0.84 & 0.13 & 0.07 & 1.04 \\
\hline
\end{tabular}

Sources: Same as Table 2.

a. All income figures are in real terms, deflated by the official consumer price index. The decomposition components are: $A=\Sigma \gamma_{i} \dot{w}_{i} ; B=\Sigma \gamma_{i} \dot{\alpha}_{i} ; C=\Sigma \gamma_{i} \dot{w}_{i} \dot{\alpha}_{i}$, where the symbols are defined as for equation (1) in the text. Differences in total changes are due to the different time periods and populations. Educational incomes are for persons 25 years and over; occupation and region, for 14 and over. The "total" change and decomposition components are approximations based on median rather than the appropriate mean income data. 
column A showing the gain due to income changes within groups; column $\mathrm{B}$ the gain due to changes in distribution across groups; and column $\mathrm{C}$ the interaction. Thus, the first figure in the table, 0.43, means that from 1949 to 1971 white male incomes within educational groups increased 43 percent on average.

That blacks made considerable gains in income within groups, as indicated in Table 2, is confirmed by the data recorded in column A. Due to rapid increases in intragroup incomes in the 1960s, rates of change among blacks exceeded those of whites over the entire period. Black women recorded the greatest gains in the A component in two of the three categories and white women the least in all three. Differential changes in income within categories were, according to the data, reinforced by significant shift and interaction effects in contributing to the advancement of blacks. In the regional data, for example, the shift from South to North raised black incomes by 12 to 13 percent, with a corresponding increase in relative incomes due to the absence of regional effects on white incomes.

Two aspects of the decomposition calculations for occupational groups provide valuable clues to the labor market developments under study. First is the sizable interaction (C) term in the decomposition of black male incomes and the large interaction and shift (B) terms for black females. In the case of men, over one-third of the 1949-69 difference between black and white income gains is accounted for by the interaction factor; for women, large gains appear in the wage and shift components as well. The implication of the positive interaction term is that shifts in the demand for black workers in the 1949-69 period raised the wages for black males differentially among occupations, inducing significant supply responses in the form of larger gains in employment in occupations with rapidly increasing wages. The movement of workers into initially high-paying jobs may also reflect a supply adjustment over time in response to an initial disequilibrium. Viewed in this way, the 31 percentage point difference in the distribution component of income changes (occupation in column B) between black and white women suggests that changes in the supply of black women among occupations played a major role in their rapid economic advance.

\section{Possible Causes of Change}

What factors in the labor market could have caused the observed changes in the black economic position? This section deals with the demand and 
supply forces in the postwar years that, a priori, appear likely to have altered the market for blacks, and develops three hypotheses to explain the patterns of change.

\section{DEMAND FOR DISCRIMINATION}

The potential effect of changes in the relative demand for black labor on income, employment, and job opportunities is best considered in the context of the standard theory of discrimination initially developed by Becker. ${ }^{17}$ In this theory, discriminatory differences in the labor market result from the nonpecuniary cost that white discriminators attach to associating with blacks at the work place. Given the opportunity of hiring black or white workers of equal productivity at the same wage rate, the discriminatory employer chooses the white because of the nonmonetary cost associated with hiring the black; similarly, faced with identical wage offers, the discriminatory white worker selects a work place where only whites are his coworkers. If the black and white populations have the same structure of skills and resources, the nonpecuniary cost of association can be avoided by segregation. With whites making up the bulk of the better-educated and skilled workers, and of managers and owners, however, association cannot be avoided and blacks must work with complementary white managerial or skilled labor. As blacks create nonpecuniary costs, however, they are obliged to accept lower pay to obtain work, compensating the employer directly or white workers indirectly for the displeasure of associating with them. The result is that the wages of similarly productive black and white workers- $\left(W_{i}^{B}\right)$ and $\left(W_{i}\right)$, respectively-will differ by an amount $D_{i}$, which represents market purchases of discrimination:

$$
W_{i}=W_{i}^{B}+D_{i}
$$

The behavior of nondiscriminators is especially important in models of this type, for they will hire or work with blacks and enjoy cost advantages in production or higher real incomes than discriminators. ${ }^{18}$ A nondiscriminating employer, for example, who pays a wage $W^{B}$ for labor that is lower than the $W$ wage of his discriminating competitor, will expand output, potentially driving discriminators out of production. Discriminatory differences due to tastes can persist for either of two sets of reasons. First,

17. Becker, Economics of Discrimination.

18. For a more detailed analysis of nondiscriminatory behavior in the context of the model, see Richard B. Freeman, "Labor Market Discrimination: Analysis, Findings, and Problem" (Harvard Institute of Economic Research, 1973; processed). 
cost curves may be U-shaped, so that nondiscriminators have limited possibilities of expansion, while the supply of nondiscriminatory employers or workers with skills complementing blacks is limited. Alternatively, nonmarket costs may prevent nondiscriminatory behavior even by those with no taste for discrimination. In years past, discrimination by southern governments in schooling and in protection of property and life constrained the supply of educated blacks, who might have competed with discriminatory whites in the market. In addition, violence outside the normal competitive system by such groups as the Ku Klux Klan, and social pressures on persons deviating from group norms, tended to penalize nondiscriminators, reducing competitive pressures against discrimination. With such collusive and nonmarket forces acting to prevent competition from eliminating discrimination, it is reasonable that taste discrimination of the Becker type persisted in the U.S. job market.

With the demand for black labor $\left(L_{b}\right)$ dependent on nonpecuniary discrimination costs $(D)$ as well as pecuniary costs, it will necessarily be less elastic with respect to money wages (holding $D$ constant) than the demand for white labor $\left(L_{w}\right)$. Formally, movements along the black and white demand schedules can be described in elasticity form thus:

$$
\begin{gathered}
E L_{b}=-\eta \frac{W^{B}}{W} E W^{B} ; \\
E L_{w}=-\eta E W,
\end{gathered}
$$

where

$$
\begin{aligned}
E & =d \log \sim \text { percent change } \\
\eta & =\text { absolute value of elasticity of demand for white labor. }
\end{aligned}
$$

The black schedule is distinguished by an elasticity with respect to wages of $\left(W^{B} / W\right) \eta$ rather than $\eta$. Since $W^{B}$ is less than $W, W^{B} / W$ will be less than unity so that equal percentage changes in black and white wages $\left(E W^{B}=\right.$ $E W)$ will alter employment of whites more than employment of blacks, discrimination costs held fixed.

\section{CHANGES IN DEMAND}

The prime determinant in this model of long-run changes in relative demand, and, other things equal, in the income of blacks is changes in market discrimination $(E D)$. In the period under study, two important forces appear to have reduced discrimination in the labor market.

The first is a change in the price or cost of discrimination ensuing from 
public and private antidiscriminatory activities associated with the Civil Rights Act of 1964 and related national policies. Title VII of the act made it illegal "to fail or refuse to hire or to discharge any individual, or otherwise to discriminate against any individual with respect to his compensation, terms, conditions, or privileges of employment, because of such individual's race, color, religion, sex, or national origin," and created the Equal Employment Opportunity Commission (EEOC) to administer this law. Executive Order 11246, which required federal contractors (who employ a significant portion of the work force) to take "affirmative action" in minority employment, and several voluntary programs such as the Plans for Progress and the National Alliance of Businessmen, were also initiated in the late sixties. Using boycotts, court cases, and political pressure, civil rights groups, whose attention had shifted from school issues to the job market, further operated to raise the cost of discrimination.

The second important development was an apparent decline in individual demandsfor discrimination, which may have resulted from autonomous shifts in taste, public educational programs, or changes in per capita income that altered purchases of discrimination as they might purchases of other goods. Data from public opinion polls provide the clearest evidence of changes in manifest discriminatory attitudes, revealing sizable declines in the percentage of whites viewing blacks as inferior and increases in the percentage favoring equal treatment in the market. ${ }^{19}$ The effect of increases in real income on the discriminatory demands of individuals, while only one of the numerous and complex factors underlying the changes in attitudes, is readily analyzable in the model of discrimination. Equation (2) makes it plain that the relative income of blacks increases (decreases) as real income increases due to general productivity gains if the income elasticity of demand for discrimination is below (above) unity. ${ }^{20}$ Since discrimination is

19. According to the National Opinion Research Center in 1944,45 percent of whites believed "that Negroes should have as good a chance as white people to get any kind of job," compared with more than 80 percent in 1963. See Mildred A. Schwartz, "Trends in White Attitudes toward Negroes," Report 119 (NORC, 1967; processed), p. 24.

20. Rewriting (2) to focus on the gap between black and white incomes yields

$$
1-W^{B} / W=D / W \text {. }
$$

Taking logarithmic derivatives with respect to changes in real income $(E Y)$ that are accompanied by a proportionate increase in wages yields

$$
E\left(1-W^{B} / W\right)=\left(\frac{E D}{E Y}-1\right) E Y,
$$

which is negative when $E D / E Y<1$, as claimed. 
surely a "habit good," however, income-induced changes in its purchase are likely to occur only slowly.

Another potentially important factor reducing discrimination-the expansion of relatively nondiscriminatory sectors of the economy, which employ many blacks and offer them better lifetime earnings opportunitiesdoes not appear to have had significant influence in the period under study. The occupations or industries with many blacks at the beginning of the postwar era, such as agriculture or domestic service, offered shrinking job opportunities as the era progressed. Moreover, while some compression in the wage structure occurred in the late 1960s which would benefit low-skill blacks, it was relatively insignificant to the overall advance of blacks.

In the short run, when demands for discrimination are roughly fixed $(E D=0)$, the model of equations (2) and (3) implies different cyclical responses of black and white incomes and employment. More precisely, since demand for black labor is relatively price inelastic because of the fixed discrimination term, equal movements in a demand schedule to the right or left over the business cycle will, as Figure 3 makes clear, have a greater impact on black than on white employment and incomes. ${ }^{21}$ In order to focus on demand behavior, assume specifically that black and white supply schedules are equally elastic $\left(E L_{b} / E W^{B}=E L_{w} / E W=\epsilon\right)$. The greater effect of horizontal shifts in demand $(E X)$ on wages and employment of blacks can be readily demonstrated as follows:

$$
\begin{array}{cl}
E W^{B}=\frac{E X}{\epsilon+\eta\left(W^{B} / W\right)} ; & E L_{b}=\frac{\epsilon E X}{\epsilon+\eta\left(W^{B} / W\right)} \\
E W=\frac{E X}{\epsilon+\eta} ; & E L_{w}=\frac{\epsilon E X}{\epsilon+\eta}
\end{array}
$$

The resulting greater responsiveness of black income and employment is consistent with, though not necessarily the major factor behind, the employment and income findings of Table 1 and the intra-occupation results of Table 4.

Finally, in view of the differential change of relative income and employment among various black groups, it must be recognized that a given change in discrimination may not have the same effect on every group of

21. Note that while equal vertical shifts have the opposite effect, changes of that type do not meet the assumption of constant demand for discrimination. An equal percentage increase in black and white wages at a given employment level must be accompanied by an equal percentage increase in $D$ for equation (2) to be fulfilled. 
Figure 3. Effects of Changes in Demand for Labor on Black Income and Employment, Given Fixed Discrimination

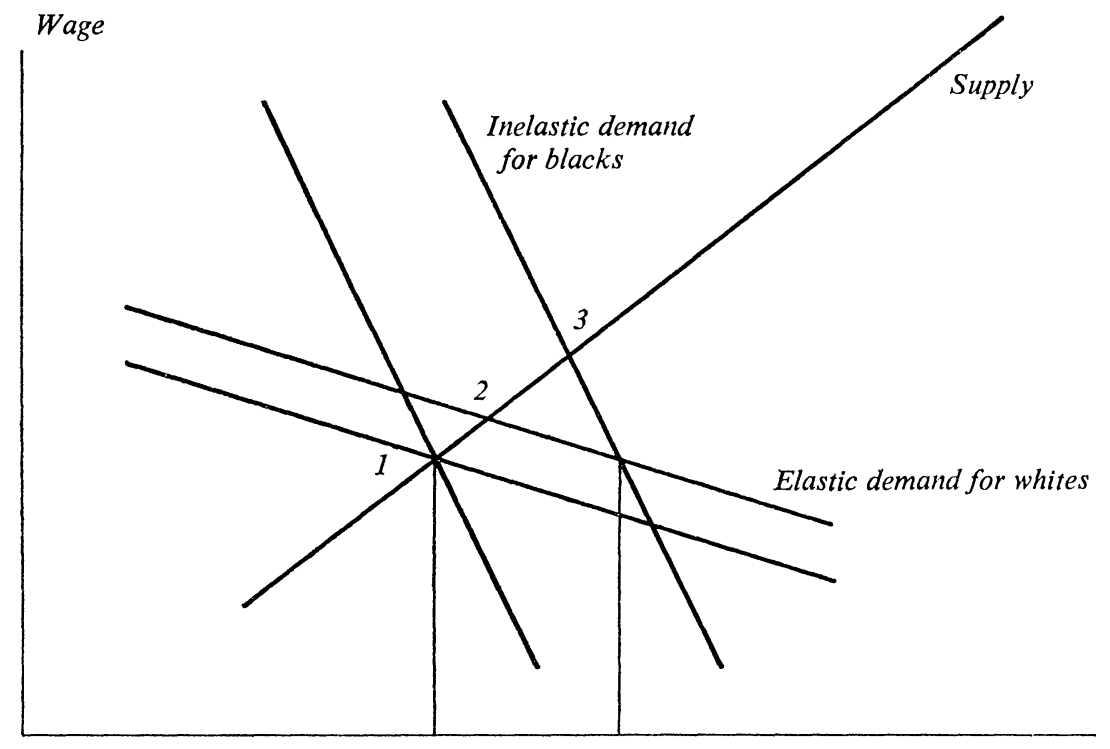

Number of workers

Note: Both initial demand curves shift rightward by the same amount throughout, measured horizontally 1 = Initial wage, employment point; the wage axis is assumed to be scaled differently for blacks and whites; $W B<W$, even though both are marked at point 1 .

$2=$ White wage, employment point after shift (elastic demand curve).

3 = Black wage, employment point after shift (inelastic demand curve).

workers. In particular, reductions in discrimination are likely to have larger immediate effects on occupations or groups of workers with flat ageearnings curves or short job ladders than on sectors of the labor market where investment in skill and accumulated experience count most. A decline in discrimination in athletics, for example, would show up first in new hires of black athletes and last in employment of managers, coaches, or executives. The implication is that an easing in discrimination will be most pronounced among the young and among women in industries where entrylevel jobs bulk large, and least marked for men requiring on-the-job accumulation of human capital.

\section{CHANGES IN SUPPLY}

Two supply-side developments were also likely influences on the black economic position in the period under study. First, the marked increase in 
the number of years of schooling of blacks could have been expected, all other things being equal, to improve their position in the job structure and in earnings. Because of differences in the relative incomes of black men and women by educational level, however, the lengthening of schooling would by itself have had strikingly different effects on the economic progress of the two sexes. With the black-white income ratio for males falling with increased education, the potential improvement in the relative economic position of black men resulting from more schooling would have been small. Indeed, the decomposition computations in Table 5 show that shifts among educational categories in the 1949-71 period raised black male incomes by just 4 percent more than they did white male incomes. (The B component for educational categories was 0.21 and 0.17 for black and white males, respectively.) The situation among females is quite different because the more educated black women had relatively high incomes even in the early postwar period. Increases in their relative educational attainment would have produced sizable economic gains over time; as Table 5 suggests, changes in education raised the incomes of black females by 11 percent more than those of white females. Taking the initial income patterns as given, increased educational attainment favored black women more than black men.

The second potential contribution from the supply side to the changes of the 1960s is the apparently sizable shift of black workers to occupations that improved their income and employment opportunities. Advances in the occupational structure and in income are likely to depend critically on how workers react to economic incentives; the more elastic the supply curve to particular occupations, the greater will be economic gains in a period of improved opportunities. ${ }^{22}$ Since the proportion of blacks in the better jobs increased significantly, and since the occupational decomposition calculations turned up positive interaction and shift terms, it is plausible to attribute some of the gain blacks made to their rapid reaction to market incentives.

Differences in the response of young workers or new entrants, on the one hand, and older workers, on the other, to improved income opportunities may explain the more rapid advance of younger blacks in the 1960s. Since the young make their career decisions contemporaneously while the deci-

22. This will not always be the case, as the more elastic the supply schedule, the smaller will be the increase in income due to the shift in demand. In the discrimination situation, however, demand for blacks is probably very inelastic, as the Civil Rights Act makes differential pay illegal. 
sions of older workers reflect past as well as current conditions, the elasticity of supply with respect to current incentives will be higher for the young. As a result, the young will make greater gains in the job structure in periods when discrimination declines and sustain greater losses when it intensifies. ${ }^{23}$ Similarly, supply responses can be expected to be more rapid in labor markets where the gross turnover of the work force is normally high, as is the case among women, because older new entrants will supplement the supply of occupationally mobile young people. In addition, the lower the on-thejob training or skill of an occupation, the more rapid will be the adjustment of its supply to economic change. These considerations supplement those given in the discussion of demand as possible explanations of differential rates of advance among groups of black workers.

\section{Explaining the Economic Progress of Blacks}

The way in which the hypothesized changes in demand and responses in supply may have operated to cause some of the observed patterns of change in the labor market for blacks described earlier can be summarized in three propositions, which will be investigated in turn.

(1) Relative demand for and income of black workers were raised in the postwar period by governmental and private antidiscrimination activity following the 1964 Civil Rights Act and possibly by a general societal decline in individual and market purchases of discrimination relative to levels of productivity.

(2) The black occupational distribution improved greatly in the $1960 \mathrm{~s}$ as a result of the significant supply response of black workers to economic opportunities, as well as of the increased relative educational attainment of the black population. Black workers shifted occupations rapidly in response to reduced discrimination and improved opportunities.

(3) Black women advanced more rapidly relative to their white counterparts than black men in part because declines in discrimination have greater effects on job markets, such as those for women, where on-the-job training and cumulated experience are less important and where gross turnover of the work force is rapid. Such markets allow older as well as younger workers

23. From 1890 to 1920 , when the blacks' relative position worsened in the South, older black workers who had been trained in previous decades continued to be important in many craft jobs, while the young were "kept out." See Richard B. Freeman, "Decline of Black Craftsmen in the South" (University of Chicago, 1972; processed). 
to take advantage of new opportunities, and, moreover, they are the special province of women. In addition, the improved economic status of black women relative to white women reflects the especially small increase in the incomes of the latter.

What is the empirical evidence for, or against, these explanatory hypotheses? How well do they account for the dimensions of change highlighted earlier? To consider these questions, the following sections examine time series and cross-sectional data.

\section{Changes in Demand for Discrimination}

The first issue to consider is the effect on the economic position of blacks of the antidiscrimination policies associated with the 1964 Civil Rights Act and the social changes it may have spurred. Evidence suggests that federal and related civil rights activities were important in the period under study. First, considerable federal resources were allocated to combat discrimination in employment. For example, EEOC expenditures in 1970 totalled more than $\$ 13$ million, far exceeding comparable expenditures by states prior to $1964 .^{24}$ The courts also interpreted the law in a manner likely to stimulate demand for black workers, pressing employers to hire members of minority groups and disallowing many employment tests that tended to exclude minorities. ${ }^{25}$

Second, unlike existing state antidiscrimination laws, which have been passed only by nonsouthern industrial states where discrimination is relatively slight in any case, ${ }^{26}$ the federal law extends to the South, which still

24. State government expenditures for fair employment practices were on the order of $\$ 1.7$ million in 1959. See William M. Landes, "The Economics of Fair Employment Laws," Journal of Political Economy, Vol. 76, Pt. 1 (July/August 1968), p. 547. Moreover, the number of cases dealt with by the EEOC in fiscal 1970 alone-16,348-nearly matched the total number of state fair employment cases in the period from the date of state laws to December 31, 1961-19,439. See Equal Employment Opportunity Act, S. Rept. 867, 88 Cong. 2 sess. (1964), p. 7, and U.S. Equal Employment Opportunity Commission, 5th Annual Report (for fiscal year 1970), p. 64.

25. In Alabama, the court has ordered that the state hire one black trooper on the state police force for every white man hired until 25 percent of the force is black. In Massachusetts, the court has suggested that blacks who have failed police examinations be employed in any case. These examples provide some notion of the way in which federal courts have interpreted the Civil Rights Act of 1964 and related legislation.

26. Such states as New York, New Jersey, and Massachusetts were among the first to pass fair employment practice laws. 
accounts for one-half of black employment and exhibits the greatest differences between black and white incomes. One indication of the extent of the federal effort in the South is the fact that two-thirds of employer-unionagency cases before the EEOC in 1970 originated there, with Texas, Florida, and Louisiana having the largest number of charges investigated. ${ }^{27}$

Third, federally required programs of affirmative action, involving job quotas that favor minorities, have made minority hiring an explicit goal of major corporations. At I.B.M., for example, every manager is told that his annual performance evaluation - on which promotions, raises, and bonuses critically depend-includes a report on his success in meeting affirmativeaction goals. ${ }^{28}$ According to a study by the Conference Board, court decisions relating to Title VII of the 1964 Civil Rights Act have spurred changes in company personnel policies and practices, with many companies employing "roving 'compliance specialists,' who visit even the most remote installations" to suggest ways to expand the number of women and minority group employees on the payroll. ${ }^{29}$

To examine whether or not governmental and related activity regarding civil rights after 1964 did, in fact, improve the black economic position, Table 6 contains several regression calculations linking black incomes and status to measures of federal antidiscriminatory policy and other potential causes of change. The dependent variables (in logarithmic form) are relative and actual incomes of black men and women and indexes of occupational position; the explanatory variables are time or the trend level of GNP (GNPT); differences in black and white years of schooling (EDUC); and the civil rights variable, cumulated real expenditure of the EEOC per nonwhite worker (EEOC). Cumulated rather than annual spending is used to measure the intensity of antidiscriminatory activity because such activity is an investment in nonwhite opportunities, reducing future as well as current discrimination. More formally, it would be proper to take account of depreciation (or possible appreciation) of civil rights resources also, but the data are not rich enough for such calculations. Alternative specifications, using annual EEOC spending per nonwhite worker, nondeflated spending, or a simple post-1964 trend variable, show the basic results to be impervious to the precise measurement of the variable. Since a wide variety of public and private activities commenced or accelerated in the 1960s, the

27. EEOC, 5th Annual Report, p. 31.

28. See Daniel Seligman, "How Equal Opportunity Turned Into Employment Quotas," Fortune, Vol. 87 (March 1973), p. 167.

29. New York Times, April 30, 1973. 
EEOC variable must be viewed solely as an index of activity and not as a measure of the effectiveness of the commission nor of the social effect of its expenditures.

The most important finding of Table 6 is that the post-1964 period did, in fact, witness an exceptional increase in black incomes, unaccounted for by previous trends, cyclical boom, or increased black educational attainment, and linked to civil rights activity. In regressions (1) and (4), the EEOC measure has a sizable significant coefficient, which implies that antidiscriminatory activity was responsible for increases in the black-white income ratio, from 1965 to 1971, of 15 percent for males and 27 percent for females, or 9 and 16 percentage points, respectively, from levels of about 60 percent in the early sixties. If the "time effect" is attributed to the growth of real GNP interacting with income-inelastic demand for discrimination, the regressions should take the form of lines 2 and 5 of Table 6 , which replace time with the trend level of real GNP (GNP predicted by a regression on time). The coefficients then suggest that a 1 percent change in real GNP over the long run raises the black-white income ratio by 0.1 percent for males and by 0.8 percent for females; in contrast, the cyclical coefficients imply that a change of real GNP of 1 percent in the short run, given the trend, adds $0.8-$ 0.9 percent to the relative incomes of both black men and women. When the difference in black and white median education replaces real GNP as a long-term variable, the results are similar: a sizable effect of education for females and a small one for males, with cyclical elasticities of the same order of magnitude. In each of these cases, the trend variables must be omitted to obtain reasonable statistical results. The cause of the trend effects, especially the large increase in the black-white income ratio for females, is not readily determined by such time series analysis. ${ }^{30}$ The point is that, however the

30. If, following Orley Ashenfelter ("Changes in Labor Market Discrimination Over Time," Journal of Human Resources, Vol. 5, Fall 1970, pp. 403-29), the effect of improved black educational attainment is specified, a priori, as the trend increase in an incomeweighted index of educational attainment, and no other differential productivity changes are assumed, the difference between estimated trend coefficients and the increase in the indexes can be taken as a measure of change in market purchase of discrimination. From 1947 to 1971, income-weighted indexes (1959 Census income weights) show a trend increase in black male productivity of 1.1 percent and in white male productivity of 0.8 percent, while female productivity increased by 1.9 percent and 0.7 percent, respectively. Subtracting the differences between the black and white rates from the coeffcients on time in equations (1) and (4) eliminates the male trend coefficients but leaves approximately half $(0.029-0.012=0.017)$ of the female trend, possibly attributable to changes in demands for discrimination, civil rights activity aside. 


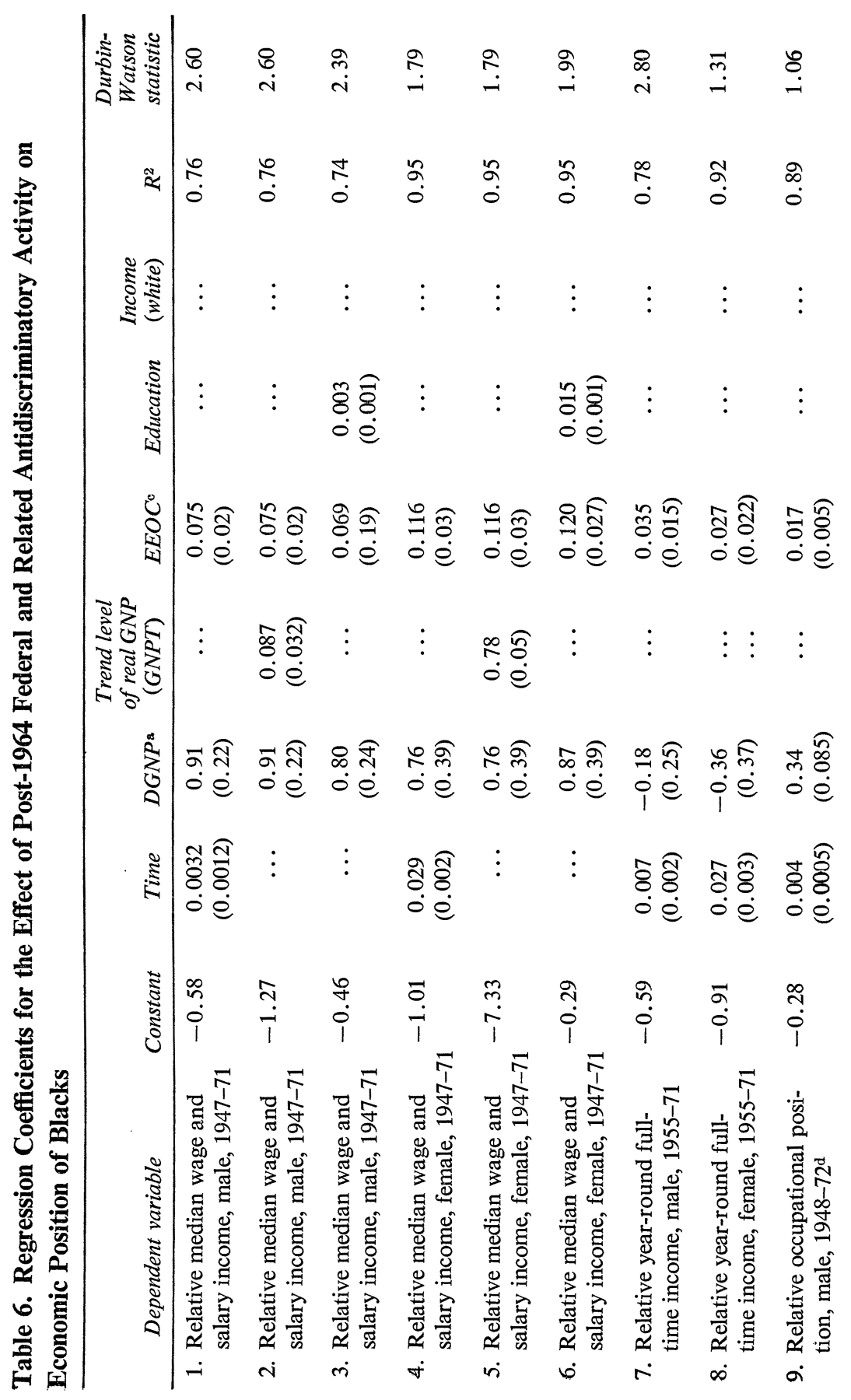




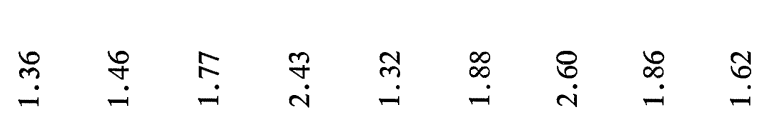
每

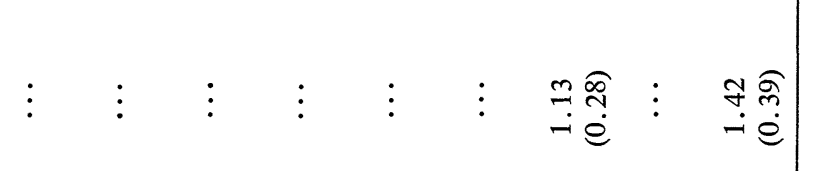

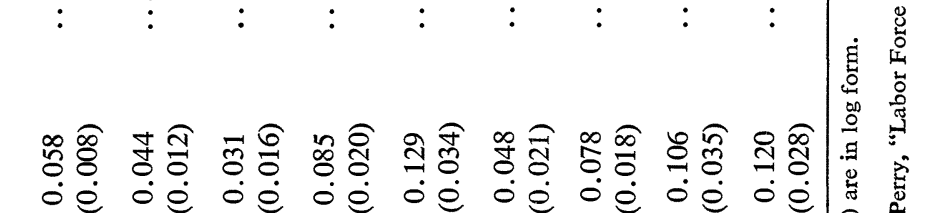

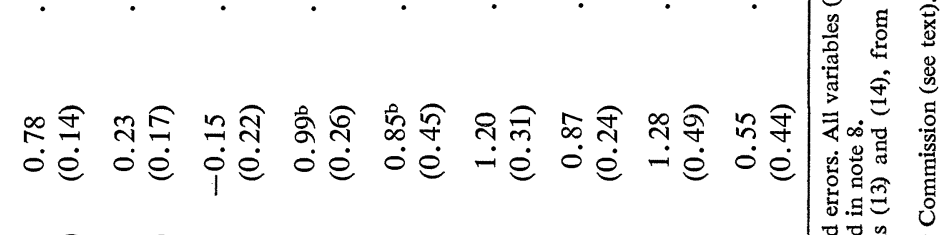

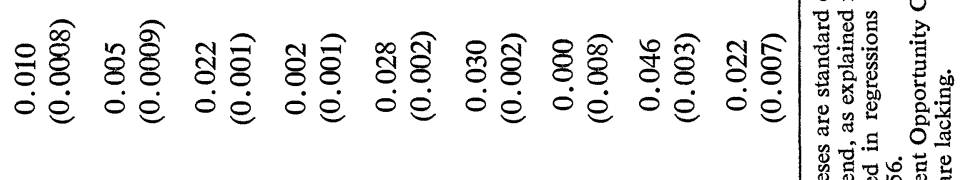
î.

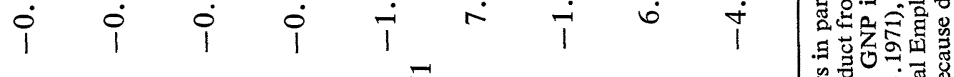

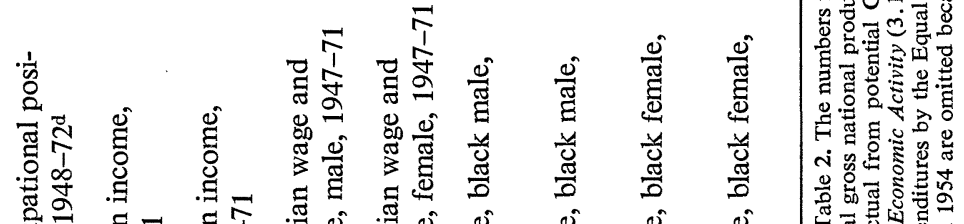

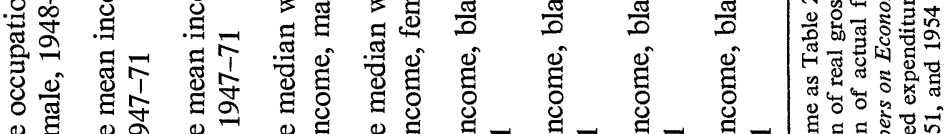

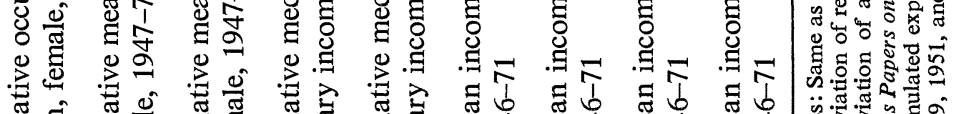

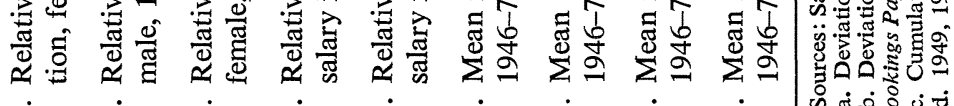

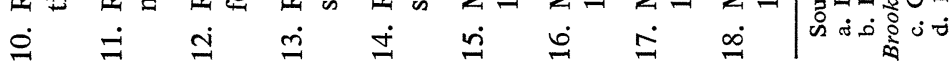


trend influence is allocated to independent variables, the EEOC effect remains about the same.

Further tests of the economic effect of civil rights activity after 1964 are reported in lines 7-14. The dependent variable is changed to the relative income of year-round full-time workers (lines 7 and 8), indexes of occupational position (9 and 10), and mean relative incomes (11 and 12). In lines 13 and 14, the deviation of GNP from its trend is replaced by the deviation of actual from potential GNP. The results confirm the hypothesized civil rights effect with a more varied set of coefficients. The biggest change is the decline in the EEOC coefficient for females when either income of yearround full-time workers or mean total income replaces the wage and salary variable. In these cases, the coefficients for females no longer exceed those for men, as they did in lines 1-6. Comparison of lines 13 and 14 with lines 1 and 4 reveals that the use of deviation of GNP from potential GNP rather than from trend as the cyclical variable has little effect on the EEOC coefficient. It remains sizable and statistically well determined. Other indicators of aggregate demand, such as the rate of unemployment, also show that boom conditions were not the principal source of the improvement in the black position after 1964, although they did benefit the relative incomes of blacks.

Finally, the use of relative income as the income variable is checked in regressions (15)-(18), which focus on the income of black men and women. In equations (15) and (17), the calculations concerning males and females yield the familiar results that the trend and civil rights variables have somewhat greater effects for women than for men, although the difference in trend coefficients for the two sexes is considerably smaller than it is in lines 1 and 4. Regressions (16) and (18) introduce incomes of white males and females, respectively, as explanatory variables. In a properly specified equation that included all the factors causing differential changes in black and white incomes, the coefficient on the white income variables would be unity. Income of white males enters regression (16) with a plausible coefficient which differs only modestly from unity; income of white females, however, shows a much larger coefficient in regression (18), indicating that the different pattern of relative incomes for females is not well explained by the model. Again, however, the size and significance of the estimated EEOC effect remains about the same as in the initial calculations.

Further computations (not reported in the table) with regional income data-incorporating the same national cyclical trend and EEOC measures 
-reveal that the developments after 1964 arose not from regional shifts but, rather, from intraregional income changes. Indeed, as might be inferred from the patterns outlined in Table 2, the regional calculations show that civil rights activity had its largest effect for men in the South. However, despite the absence of a rising trend in the black-white income ratio for males in the Northeast, the EEOC variable is accorded a sizable positive coefficient on income in that region, counterbalanced by a negative time coefficient. In the absence of independent variables by region, however, it is not feasible to estimate from these data the differential effect of antidiscriminatory activities on the economic position of, say, northern and southern blacks.

The regressions in Table 6 cannot be viewed as conclusive evidence regarding the proposition that civil rights activity raised demand for black labor in the late 1960s. They would be misleading if in fact some other factors specific to the period since 1964 but omitted from the analysis were the cause of the observed developments. What these other factors might be, however, is difficult to say, and in the absence of contrary evidence, I conclude tentatively that federal policy and civil rights activities underlie the increase in black incomes in this period. If, in the future, rises in relative black income should coincide with a relaxation of antidiscriminatory activity, or relative income should decline despite the continuation of such activity, or more refined calculations become possible, this conclusion would have to be reexamined.

\section{Supply-side Developments}

To what extent does the movement of black Americans up the occupational ladder reflect economic responsiveness on their part in occupational decisions? This question is examined next by estimating supply equations relating changes from 1960 to 1970 in the number of black men in approximately fifty detailed occupations to measures of economic incentives, using data from the 1960 and 1970 Censuses. The occupations covered range from specialized professions, such as architecture, to the broad laborer category, and include the bulk of the male work force. In the decade under study, the data show considerable variation in the rate of change of black employment for these occupations, ranging from expansions exceeding 100 percent in such fields as accounting and engineering to declines in farming. To pin 
down changes in the career decisions of men with specified levels of schooling, as opposed to changes associated with increased attainment, men with grade school training only, and high school and college graduates, are examined separately. The basic regression calculations appear in Tables 7 and 8 , which focus, respectively, on logarithmic changes in the number of black workers in each occupation and in the proportion of workers in an occupation who were black. The independent variables are income incentives in 1960 or 1970 and the number (proportion) of black workers by occupation in 1960, all in log form. The lagged number or proportion term is expected to have a negative coefficient, since occupations with relatively many workers will, in general, have smaller percentage changes in numbers than those with few workers. Observations are weighted by the number of blacks in the occupation in 1960 so that large changes in small fields (architecture, for instance) do not dominate the regressions.

The equations are expected to identify supply (rather than demand) behavior because the demand for black labor shifted substantially in the 1960s, and, according to previous findings in this paper, that shift resulted from antidiscriminatory policies. The shift in demand presumably occurred unevenly across occupations, being most pronounced in occupations in which blacks had previously been sparse (construction trades, college teaching, for example), and least marked in traditional areas of black employment (such as farming and services). In general, sizable shifts in demand trace out the relevant supply schedule in a body of data, unless the latter also shifted considerably. To minimize that possibility or its effect on the estimates, several techniques were used. First, the analysis was focused on specific groups-persons of the same age or with the same amount of schooling-who would be expected to have a more stable and better-defined supply schedule than the broad population. ${ }^{31}$ Because young persons, in particular, have just entered the labor force, they can be regarded as responding to a given wage structure that they have not yet significantly influenced. Second, since in many occupations lengthy training periods cause changes in supply to lag behind economic incentives, 1969 income is replaced in some calculations by 1959 income. Use of the 1959 wage structure avoids problems of two-way causation; it may have affected the flow of manpower to occupations in the 1960s, but could not have been affected by that subsequent flow. Finally, the computations were also made with the

31. See Richard B. Freeman, "The Implications of the Changing Labor Market for Members of Minority Groups," in M. S. Gordon (ed.), Higher Education and the Labor Market (McGraw-Hill, 1973). 


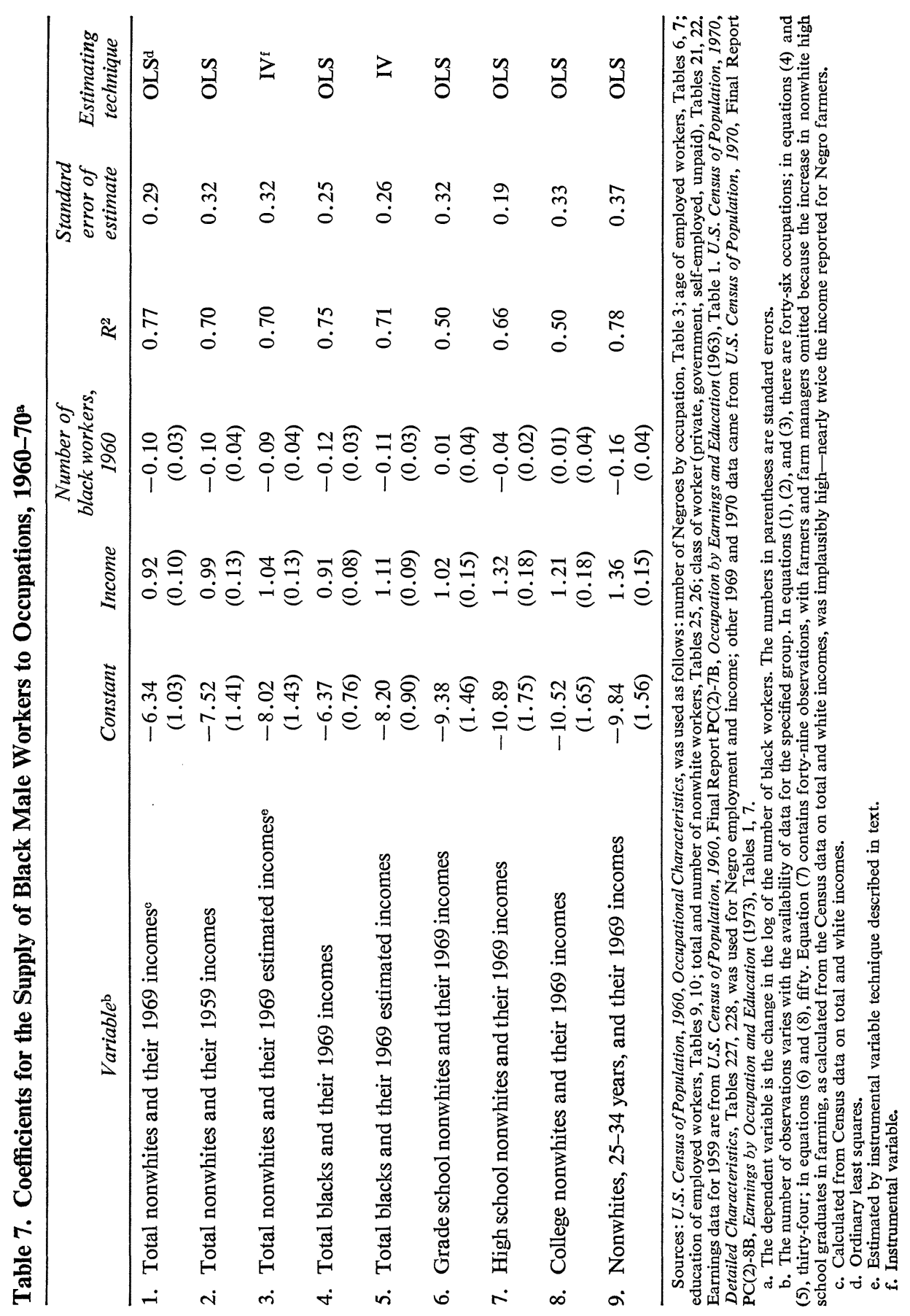




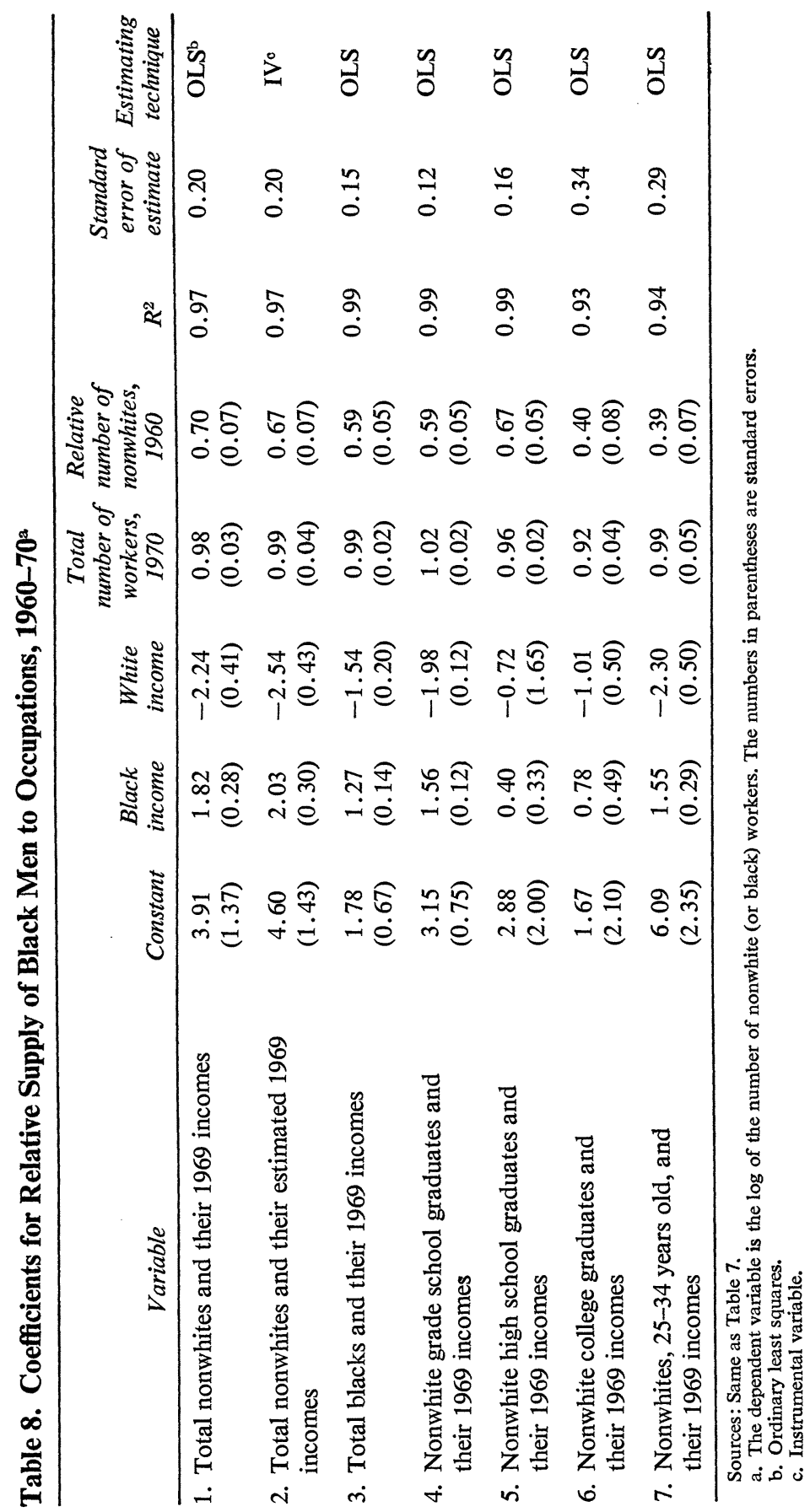


statistical technique of instrumental variables..$^{32}$ Even with these refinements, the calculations are offered as crude first-order approximations to the behavior under study. For one thing, total income, rather than the more appropriate rate of return of investment in the occupation, is used as a measure of incentives; second, the cross-sectional calculations implicitly assume that workers considering an occupation compare wages with the average for all occupations, rather than with some close alternatives. Perhaps further analysis of the 1970 Census data will repair these weaknesses.

\section{REGRESSION RESULTS}

The regression results in Tables 7 and 8 strongly support the hypothesis that the occupational structure of the black work force was significantly affected by economic incentives in the period under study. In all of the diverse computations, the income incentive variable obtains a large and reasonably well-defined positive coefficient.

More precisely, lines 1-3 in Table 7 record the results of regressions of the proportionate change in the number of nonwhite men, 1960-70, on the number in 1960 and on income for either 1969 or 1959. In line 3, the income variable is an estimate of 1969 income obtained from the instrumental variable regression. In all cases, the estimated elasticity of supply to income is approximately unity; and the lagged employment variable is generally accorded a small negative coefficient. While the bulk of the variation in employment changes among occupations is accounted for by the regressions, the standard error of estimate, on the order of 0.30 , indicates that considerable unexplained change remains. The regressions in lines 4 and 5 replace the nonwhite male variable with Negro men and nonwhite income with Negro income, with little substantive change in the results.

Finally, to obtain a better fix on the responses of different groups of workers, regressions were run of the changed number within occupations of nonwhite male grade school, high school, and college graduates, and of 25-34-year-olds, on the income of workers with those characteristics in the various occupations; the results are recorded in lines 6-9.

These calculations yield higher elasticities for the more educated and

32. The instruments include, in addition to the exogenous variables in the supply equation, the percentage of workers in an occupation employed by the government and by private industry, and the 1959 incomes. 
younger workers. The elasticity for those aged 25-34 years is 50 percent larger than that for all men, while by contrast, grade school graduates have the smallest estimated elasticity. These calculations are thus consistent with the argument that the greater gains of younger black men reflect, in part, the greater flexibility of their career decisions in response to economic change.

\section{RELATIVE SUPPLY}

Table 8 presents an analogous set of computations for the relative number of black workers within given occupations. The dependent variable is the number of blacks, with the total size of the occupation introduced on the right-hand side of the equation. Since the coefficient on the total size emerges from the calculations, rather than being predetermined as unity, the specification of the relative supply function can be "tested"; a coefficient of unity implies a reasonable specification. The results in the table confirm the hypothesized effect of black and white incomes on relative supply in all cases: An increase in black income in an occupation raises the proportion of blacks in that occupation; an increase in white income depresses it. In addition, the coefficient on total size is about unity, as required in the model.

While the overall results support the hypothesized supply behavior, some of the calculations-such as equation (5) for high school graduates-yield small and poorly determined income coefficients. This contrasts with the results in Table 7 and suggests the value of a more extensive study of the supply of black and white workers within education and age categories. Analysis of the factors that determine expected income prospects in a period of substantal change for blacks is, in particular, needed to provide better estimates of the relevant supply elasticities. The 1960 proportion of nonwhite (or black) workers is accorded a marked effect on the 1970 proportion, giving some notion of the speed with which past occupational distributions are altered. Coefficients on the order of 0.6 to 0.7 indicate that, after four decades, only traces of the initial distribution survive. Specifically, this implies that, in the absence of discrimination, about forty years would be required for past discriminatory differences in the occupational structure essentially to disappear. ${ }^{33}$

33. Calculated by treating occupational employment as a first-order Markov process with an effect of the past of 0.6 to 0.7 . Thus, in forty years, the impact of current em- 


\section{The Relative Advance of Black Women}

Some further light can be shed on the especially large economic gains of black women relative to their white counterparts by investigating femalemale income ratios by race and changes in the occupational structure of black women and men compared to whites.

\section{FEMALE-MALE INCOME RATIOS}

Tables 9 and 10 examine in detail the income patterns underlying the extraordinary increase in the relative economic position of black women, using data from four income series to calculate female-male income ratios by race. Two important findings emerge from the tables. First, in the 1960s, black women experienced significant increases in income relative to black (or white) men as well as white women. ${ }^{34}$ In the data series of Table 9, the female-male income ratios rose by 5-10 points among blacks but varied little, on the whole, for whites. Much of the increase appears to have occurred early in the decade, prior to the impact of the 1964 Civil Rights Act. The median wage and salary figures show, for example, a gain of 8 percentage points for black women from 1959 to 1965 (possibly reflecting cyclical factors) and a gain of 2 percentage points thereafter.

The second finding is that within major occupations black women did not obtain greater increases in income than black men. Table 10 shows greater increases in female-male income ratios in some occupations for

ployment on the number of workers will be $(0.6)^{4}$ or $(0.7)^{4}$, or 0.13 to 0.24 . Since in forty years the bulk of the current work force will have retired, the time horizon is quite reasonable.

34. This was not the case in the 1950s. During those years black-white income ratios for females rose, largely as a result of a slow increase in white female incomes; black female, black male, and white male incomes increased at about the same rate in the 1950s. It is not clear what caused the slow increase for white women.

The most obvious answer-increases in part-time work accompanying the growth of labor participation-does not appear to explain the phenomenon. In 1949, full-time women workers earned $\$ 2,003$ per year compared with $\$ 3,090$ for full-time male workers; by 1959 , full-time incomes of females had increased by 58 percent to $\$ 3,161$ while fulltime incomes of males increased by 73 percent to $\$ 5,354$; 48 percent of women workers were full-time in 1949 and 46 percent in 1959. One possibility is that white women, who unlike black women obtained relatively high-wage factory work during World War II, returned to the household and lost their accumulated experience. Another is that the increased participation of white women drove wages down. Detailed analysis of these or other possibilities lies beyond the scope of this paper. 
Table 9. Comparison of Male and Female Incomes Using Various Data Series, by Color, 1959, 1965, and 1969

Incomes in dollars

\begin{tabular}{|c|c|c|c|c|c|c|}
\hline \multirow{2}{*}{$\begin{array}{l}\text { Income series } \\
\quad \text { and sex }\end{array}$} & \multicolumn{3}{|c|}{ Nonwhite } & \multicolumn{3}{|c|}{ White } \\
\hline & 1959 & 1965 & 1969 & 1959 & 1965 & 1969 \\
\hline \multicolumn{7}{|c|}{$\begin{array}{l}\text { Median wage or salary income } \\
\quad \text { (Current Population Survey) }\end{array}$} \\
\hline Female & 1,289 & 1,811 & 2,884 & 2,422 & 3,021 & 3,640 \\
\hline Male & 2,844 & 3,432 & 5,237 & 4,902 & 6,052 & 7,859 \\
\hline Ratio, female to male & 0.45 & 0.53 & 0.55 & 0.49 & 0.50 & 0.46 \\
\hline \multicolumn{7}{|c|}{ Median income (Census data) } \\
\hline Female & 1,320 & $\ldots$ & $3,008^{a}$ & $2,333^{b}$ & $\ldots$ & $3,649^{b}$ \\
\hline Male & 2,750 & $\ldots$ & $5,194^{\mathrm{a}}$ & $4,720^{b}$ & $\ldots$ & $7,609^{b}$ \\
\hline Ratio, female to male & 0.48 & $\ldots$ & $0.58^{\mathrm{a}}$ & $0.49 \mathrm{~b}$ & .. & $0.48^{\mathrm{b}}$ \\
\hline \multicolumn{7}{|c|}{$\begin{array}{l}\text { Median total money income } \\
\text { (CPS) }\end{array}$} \\
\hline Female & 809 & 1,213 & 1,848 & 1,313 & 1,648 & 2,182 \\
\hline Male & 1,977 & 2,672 & 3,992 & 4,208 & 5,135 & 6,765 \\
\hline Ratio, female to male & 0.41 & 0.45 & 0.46 & 0.31 & 0.32 & 0.33 \\
\hline \multicolumn{7}{|l|}{ Mean income (CPS) } \\
\hline Female & 1,246 & $1,658^{\mathrm{c}}$ & $2,448^{a}$ & 1,908 & $2,273^{\mathrm{c}}$ & 3,009 \\
\hline Male & 2,434 & $3,337^{\mathrm{c}}$ & $4,361^{\mathrm{a}}$ & 4,707 & $5,555^{\mathrm{c}}$ & 7,508 \\
\hline Ratio, female to male & 0.51 & $0.50^{\mathrm{c}}$ & $0.56^{\mathrm{a}}$ & 0.41 & $0.41^{\mathrm{c}}$ & 0.40 \\
\hline
\end{tabular}

Sources: U.S. Bureau of the Census, Current Population Reports, Series P-60, relevant issues; U.S. Census of Population, 1960, Occupational Characteristics, Tables 25, 26, and U.S. Census of Population, 1970, General Social and Economic Characteristics, Final Report PC(1)-C1, United States Summary (1972), Table 94; Bureau of the Census, Trends in the Income of Families and Persons in the United States, 1947-1964, Technical Paper 17 (1967), Table 35.

a. Negroes only.

b. Data for total labor force. Data for whites only are not separately available.

c. 1964 data.

blacks, but smaller ones in others. This mixed pattern suggests that changes in the occupational distribution of black women-a more rapid upgrading than men experienced-formed the principal factor behind the greater improvement in their income.

This lead is pursued further by comparing the rates of change in incomes of black females and males and indexes of occupational position in the 1960s. From 1959 to 1969, the average incomes of black females and males approximately doubled; the improvements in occupational position were 33 percent and 14 percent, respectively, indicating that the differential income gain of women was the result of occupational upgrading. Similarly, the black-white income ratio for females increased from 0.65 to 0.82 in the 
Table 10. Comparison of Male and Female Incomes, by Occupation and Color, 1959 and 1969

Female-male median income ratios

\begin{tabular}{llllll}
\hline \multirow{2}{*}{\multicolumn{1}{c}{ Occupation }} & \multicolumn{2}{c}{ Nonwhites } & & \multicolumn{2}{c}{ Total labor force } \\
\cline { 6 - 7 } \cline { 6 - 7 } \cline { 5 - 6 } & 1959 & 1969 & & 1959 & 1969 \\
\hline Professional and technical workers & 0.77 & 0.80 & & 0.55 & 0.56 \\
Managers, officials, and proprietors, except farm & 0.49 & 0.70 & & 0.50 & 0.49 \\
Clerical workers & 0.74 & 0.67 & & 0.62 & 0.58 \\
Sales workers & 0.56 & 0.49 & & 0.32 & 0.28 \\
Craftsmen & 0.70 & 0.66 & & 0.56 & 0.54 \\
Laborers except farm and mine & 0.67 & 0.70 & & 0.65 & 0.64 \\
Service workers except private households & 0.55 & 0.63 & & 0.43 & 0.45 \\
Private household workers & 0.56 & 0.59 & & 0.59 & 0.52 \\
Farm laborers and foremen & 0.68 & 0.44 & & 0.53 & 0.42 \\
Farmers and farm managers & 0.73 & 1.05 & & 0.40 & 0.47 \\
\hline
\end{tabular}

Sources: U.S. Census of Population, 1960, Occupational Characteristics, Tables 25, 26; and U.S. Census of Population, 1970, Detailed Characteristics, Table 227.

sixties, while the ratio of occupational position advanced from 0.63 to 0.80 . Comparable changes for men were 7 and 8 points, respectively.

More formally, regressions of the female-male income ratio for blacks $(R B L)$ on the occupational indexes for the period 1948-72 (omitting 1949, 1951, and 1954 for lack of data) reveal a positive link between income ratios and occupational ratios:

$$
\begin{gathered}
R B L=+0.97+2.08 \text { ROC }-0.59 D G N P \\
(0.24)(0.28) \quad(0.54) \\
R^{2}=0.75 .
\end{gathered}
$$

$$
\begin{aligned}
& R B L=-0.17+0.95 R O C+0.05 D G N P+0.012 t \text {, } \\
& \text { (0.56) (0.58) } \\
& (0.58) \\
& (0.005) \\
& R^{2}=0.81 \text {. }
\end{aligned}
$$

where all variables are in $\log$ form and $R O C$ is the black female occupational index relative to the black male index; standard errors are in parentheses below the coefficients. As expected, the improvement in the job distribution for black females relative to that for black males raises the relative income position of the women. With the relative occupational index and the femalemale income ratio trending upward, however, the calculations are highly sensitive to specification of collinear trend variables. Addition of time $(t)$, for example, alters the $R O C$ coefficient greatly. 


\section{OCCUPATIONAL ADVANCE: BLACK FEMALES VERSUS BLACK MALES}

Why were black women able to move up the job ladder more rapidly than black men? Perhaps the nature of most jobs for women, which have relatively flat age-earnings profiles, enabled old as well as young black women to shift into better-paying occupations in response to opportunities, while the experience and training required of jobs typically for men prevented older black men from also advancing. This hypothesis is examined in Table 11, which displays the occupational progress of cohorts of black workers in the 1960-70 decade. The table records the ratio of black and white occupational indexes (weighted by 1959 income) and the change in relative indexes. The data show, as hypothesized, that older black women made sizable gains in the job structure compared to whites, while older black men did not. Between 1960 and 1970, for example, black women who were 35-44 in 1960 improved their relative occupational position by 6 percentage points and those who were $45-54$ advanced by 7 points-trends similar to those in cohort income ratios reported in Table 3. Older black men, by contrast, gained no more than 2 percentage points in relative occupational position.

\section{COHORTS AND NEW ENTRANTS}

The process of occupational change in a population involves both the shift in jobs by experienced cohorts and differences in the distribution

Table 11. Relative Occupational Position of Black Workers, by Age, Cohort, and Sex, 1960 and 1970

Black-white occupational index ratio, income weighted ${ }^{\mathrm{a}}$

\begin{tabular}{cccc}
\hline $\begin{array}{c}\text { Cohort by sex, and } \\
\text { age in 1960 }\end{array}$ & 1960 & 1970 & $\begin{array}{c}\text { Change, } \\
1960 \text { to 1970 }\end{array}$ \\
\hline Male & & & \\
$25-34$ & 0.82 & 0.86 & 0.04 \\
$35-44$ & 0.81 & 0.83 & 0.02 \\
$45-54$ & 0.81 & 0.81 & 0.00 \\
& & & \\
Female & & & \\
$25-34$ & 0.73 & 0.86 & 0.13 \\
$35-44$ & 0.68 & 0.74 & 0.06 \\
$45-54$ & 0.62 & 0.69 & 0.07 \\
\hline
\end{tabular}

Sources: Same as Table 7.

a. The indexes are calculated with 1959 total income weights. 
among occupations of retiring and entering workers. Table 12 investigates these two forms of adjustment for the black work force in the 1960s. Columns 1 and 2 record the proportionate distribution among major occupations of a single black cohort, persons aged 35-44 in 1960 and 45-54 in 1970; column 3 gives the difference in these distributions for each occupation, and column 4 the comparable change for whites. The rest of the table focuses on new entrants and retiring workers, comparing the occupational distribution of persons entering the labor market in the 1960s (aged 25-34 in 1970) with those likely to retire in the decade (55-64 in 1960).

The most striking change for black females aged 35-44 in 1960 was the movement out of household services. Between 1960 and 1970 the proportion of black women working as domestics declined by 8 percentage points; the percentages employed as service workers and as operatives rose by 5 points and 2 points, respectively, while the percentage of white women working as operatives fell by 4 points. Since domestics have very low money income, the shift from these to other jobs underlies the improved relative income position of older black women; some of the improvement must, however, be viewed as spurious, because the omission of income in kind of household workers from the calculations causes an understatement of their real income.

When the occupational distributions of black women entering and leaving the labor market in the 1960s are compared, the decline in domestic work is even more striking, viewed by itself or relative to the pattern of change for white women. Over half of the older black women leaving the work force in the 1960s were domestics; just 8 percent of those entering worked in household services. The flow of younger blacks into clerical jobs appears to be the major factor behind the rise in the black proportion of female clerical work; few older women contributed to it.

While the black men aged 35-44 at the beginning of the decade also progressed up the occupational hierarchy in the sixties, their advance was smaller than that of the women. In particular, the proportion of this black cohort working as managers increased only from 3 percent in 1960 to 6 in 1970, compared with a gain from 13 to 19 percent for whites. Differences between the distribution of male new entrants and retiring workers, while sizable, were not as great as those for women, since the men had no shift equivalent to the marked decline in private household work among women.

In sum, the evidence examined here indicates that the greater occupational mobility of older black women, especially from domestic services, 


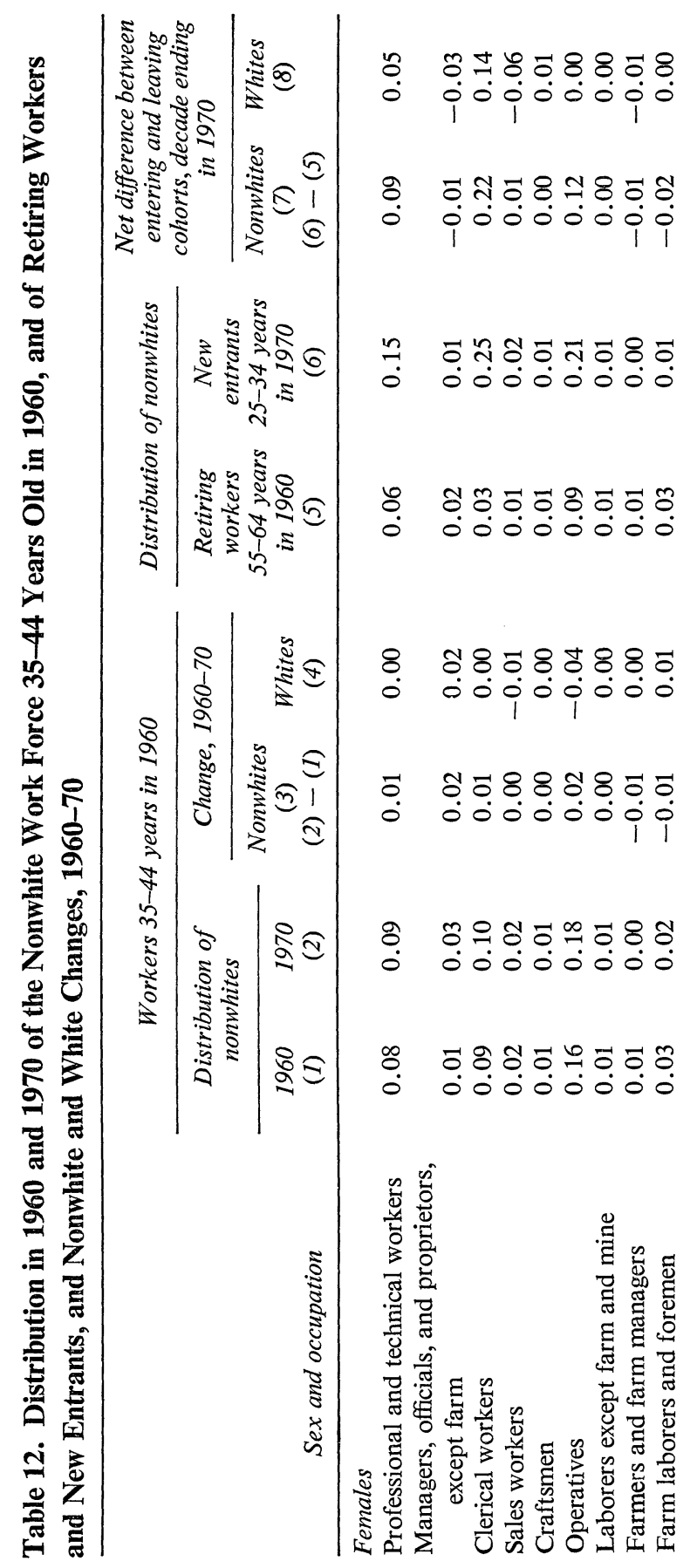




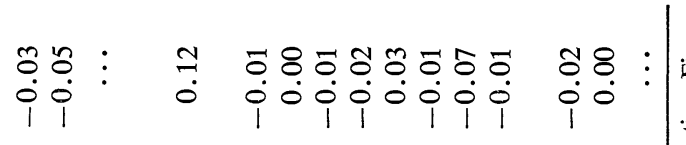
繁 ภำ

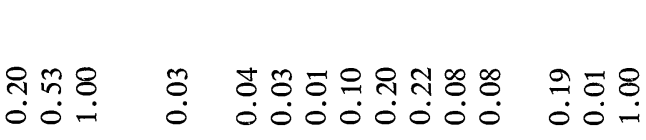
인

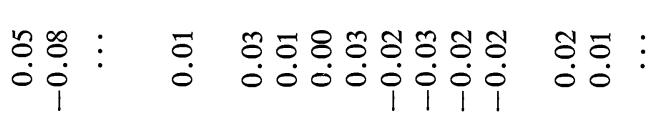

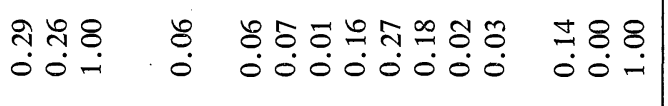
势势足

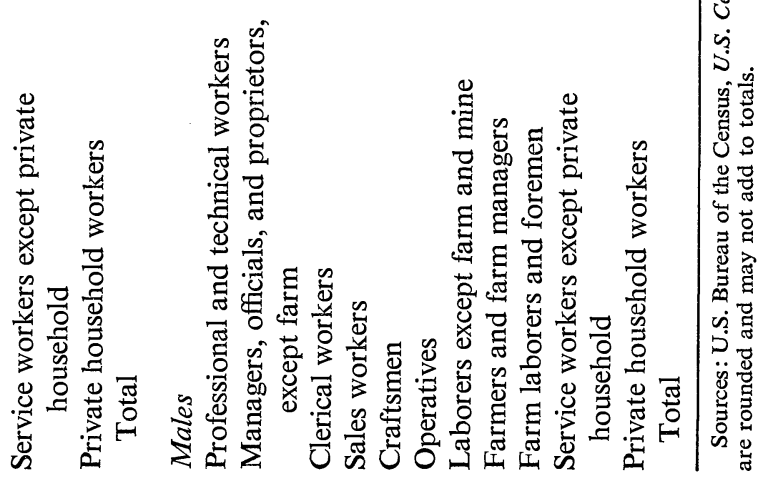


and the difference in the relative number of new entrants and retiring workers in this occupation, contributed to the extraordinary improvement in the economic position of black women. Given the relatively flat age-earnings profiles in female occupations, the data are consistent with an explanation of changes based on the ease of entering high-paying occupations for females, as compared with high-paying occupations for males. Further work on the differences in job activity between men and women is required, however, to pin down the factors that differentiate the work men and women do and that enabled black women to shift into better jobs so rapidly.

\section{Conclusions}

The major findings of this paper can be summarized briefly:

(1) The income and occupational position of black workers improved significantly relative to those of whites in the sixties-in some instances continuing a trend that had begun earlier. Specific groups of black workerswomen, young men, young male college graduates-experienced especially large economic gains. By the 1970s black women had earnings as high as, or higher than, comparable white women in the country as a whole; young black male college graduates earned as much as their white counterparts; and the black-white income ratio for young men in general was 0.85 , considerably above ratios in years past. As a result of increased incomes for highly educated and skilled black workers, the historic pattern of declining black-white income ratios with ascending skill no longer prevails. All told, these advances suggest that traditional discriminatory differences in the labor market are abating rapidly.

(2) While the story for blacks in general is of sizable economic gains, older black men appear to have made much smaller gains relative to whites than females or young men beginning their careers in the period under study. Income ratios and indexes of occupational position increased, at best, by a few percentage points for older men and their labor force participation rate declined greatly in the 1960s. The need for considerable experience or on-the-job training to advance in the male occupational structure may explain the lack of improvement for older men, despite the waning of discrimination. The fall in male participation is an important postwar development uncovered but not analyzed in this paper. It could conceivably 
be related to the increased number of families headed by women among blacks, to the incentive that the welfare system has given to the formation of such families, and to the higher female-male income ratio of blacks in the 1960s.

(3) Much of the improvement in the black economic position that took place in the late sixties appears to be the result of governmental and related antidiscriminatory activity associated with the 1964 Civil Rights Act. Previous time trends, more education for blacks, and the general boom of the period cannot account for the sharp increase in relative incomes and occupational position of blacks after 1964.

(4) Black male income and employment are strongly cyclical, rising relatively in expansions and falling in recessions. Within occupations, black employment also has more pronounced cyclical fluctuations than white employment. Among the possible causes of these patterns is the fixed cost that discrimination attaches to black workers.

(5) The economic position of black women improved exceptionally rapidly after World War II largely as a result of their movement into higher-paying occupations. An important factor in that occupational mobility was the ability of older black women to move from household services into better-paying occupations with flat age-earnings profiles and presumably few requirements of cumulated experience or on-the-job training. There was, in addition, an enormous difference in the job distribution of entering and retiring black women; the bulk of the latter and few of the former were in household services, and many entrants were in clerical positions. By contrast, older black men made little occupational progress in the 1960s and younger men made smaller gains than younger women, presumably because of the experience and training needed for high-paying male jobs, such as management.

(6) The supply of blacks to occupations was significantly influenced by income opportunities in the 1960s, and black workers moved rapidly into high-paying jobs they had previously rarely occupied. Younger workers evinced the largest supply elasticities, about 1.6 compared with about unity for older workers. The ratio of blacks to whites in an occupation also reflected responses to economic incentives, with elasticities with respect to relative wages generally ranging between 1 and 2 . When economic opportunities improved, the black population responded significantly, reducing black-white differences at a rapid rate. 
All told, the evidence presented in this study tells a remarkable story of social and economic change in the sixties. Discriminatory differences that had persisted for decades began collapsing with surprising speed. Black workers responded to these new opportunities by moving rapidly into more remunerative occupations. While additional analysis may modify or overturn some of these interpretations, it will be unlikely to gainsay the major finding of dramatic economic progress for black Americans in a relatively short time. 


\section{Comments and Discussion}

R. A. Gordon: Richard Freeman has provided a useful analysis of the labor market gains of black Americans during the postwar period. $\mathrm{He}$ documents general impressions, but the tenor of his findings is that the improvement in the relative wages, incomes, and occupational status of blacks has gone further than most observers have assumed.

I accept the general conclusion that the economic position of blacks has improved, but I suggest that the author should be a bit more judicious in his use of adjectives. Blacks have made significant economic advances, but is the author justified in concluding that "traditional discriminatory differences in the labor market are abating rapidly"? And has the economic progress of black Americans been truly "dramatic," given their still underprivileged position with respect to wages and unemployment, not to mention the housing segregation and the other economic disadvantages that blacks-and other minority groups-still endure?

First, I shall offer some detailed criticisms of what Freeman tries to do, and, second, some more general comments, including discussion of significant factors that he has omitted. On the technical side, Freeman's regression analysis leaves me a bit uncomfortable. In an almost mechanical way, he uses linear-logarithmic regressions, even though his charts and text indicate that this specification is inappropriate. Thus, Figure 1 reveals that the improvement in the relative position of black males, as measured by three different variables, did not come until the sixties-and, for wage and salary income, not until about 1966. Yet the author's regressions posit a simple 
linear-logarithmic relation with time for the entire period from the late 1940s to the early 1970s. Actually, the coefficient of relative wage and salary income on time seems to be very slightly negative from the Korean war to about 1965 . How, then, are we to interpret coefficients on time applying to the entire period, 1947 to 1971 ? The same criticism applies to many of Freeman's regressions, which apply to the entire postwar period even though his text emphasizes the improvement in the relative position of blacks since the mid-sixties. Apart from civil rights legislation and related developments in the sixties, other examples of changes in trend during subperiods of the fifties and sixties are ignored. In one set of regressions in the latter part of his paper Freeman does introduce expenditures by the Equal Employment Opportunity Commission (EEOC) as an explanatory variable to allow for one aspect of this problem.

In some cases, as in Table 1, where regression coefficients for blacks and whites are fairly close together, the author makes no attempt to test for the significance of the difference between these coefficients. In fact, throughout the paper, I learned a good deal more from his descriptive tables, with their subperiods and subclassifications, than I did from his regression results.

I now turn to more substantive matters. In Table 2, I was particularly struck by the evidence from CPS data that gains in relative income for black males, even in the 1960s, were pretty much confined to the South and West, and were barely present in the Northeast and North Central regions. While Freeman does point to Census data for this period that indicate some gains in relative incomes for nonsouthern black men, and substantial ones for black college graduates in the North and West, I am still uneasy as to how much of the overall improvement is due to such intraregional gains outside the South. My suspicion remains that migration out of the South plays a more important role in the progress than Freeman explicitly recognizes.

The pattern of gains within occupations shown in Table 2 does not square uniformly with Freeman's interpretation. In some of the occupations, for both males and females, the gains in relative incomes were at least as large in the 1950s as they were in the 1960s, and in others they were even larger. This was true in the professional group for both sexes, for example, and in the clerical and sales groups for females. In this connection, I might add that, in some work that I have done, I discovered that the nonwhite percentage of total employment in the professional-technical group increased more during 1957-63 than during 1963-69. The same was almost, but not quite, true for managers and proprietors. 
Let me next note some areas that get inadequate attention in Freeman's study. Trends in unemployment and in labor force participation deserve more emphasis. He says virtually nothing about the large increase in the ratio of unemployment of blacks to that of whites in the first decade and a half of the postwar period. Although the ratio of the unemployment rate of black males to that of white males declined significantly in the 1960s, this ratio was merely back by the beginning of the 1970s to its level at the beginning of the 1950s. And the relative unemployment rate for black women showed a net increase during the 1960s and was much higher than it had been twenty years earlier.

I am particularly disappointed that Freeman has paid so little attention to the dramatic decline that has been occurring in labor force participation rates for black males, a trend that shows up even for men under the age of 45 and which, if anything, accelerated in the latter part of the 1960s. How is this to be reconciled with the relative improvement of black incomes?

There is furthermore no mention of housing or of living conditions in urban ghettos in the paper. How much of the measured increase in real income, as conventionally defined, needs to be offset by changes in living conditions in the urban ghettos as blacks have crowded into northern cities seeking higher-paid jobs?

I shall conclude with a brief comment about the analytical treatment in the latter part of the paper in terms of changing demand and supply conditions. Frankly, I gained little from the author's discussion of the "demand for discrimination." And I find his discussion of what he calls supply factors awkward, at best. I think that an analysis in terms of a segmented labor market and barriers to mobility among submarkets would have been more illuminating. In this connection, I am a bit surprised that the author could reach the end of his paper without mentioning even once the growing literature on the dual labor market.

Duran Bell: The paper by Richard Freeman represents an enormous effort in manipulating and analyzing data from the Current Population Survey (CPS) and the decennial Census. The data and many of the regressions will certainly be of great value to me in my work. However, the text surrounding the data is amazingly dissonant with some of the numbers presented.

Freeman draws from his material two conclusions on which I would like to focus attention: First, he finds that, "while black-white differences have not disappeared, the convergence in economic position in the fifties and 
sixties suggests a virtual collapse in traditional discriminatory patterns in the labor market"; second, that the slopes of the lifetime earnings trajectories of black and white males are similar, so that relative gains made by young black workers will be maintained throughout their lives.

The data not only fail to support these conclusions but, indeed, suggest the very opposite. I shall use Freeman's material, as well as an excellent recent paper by Wayne Vroman, to support my view that these two key conclusions are absolutely false. I shall focus exclusively upon the analysis of white and nonwhite men.

Both Freeman and Vroman use CPS data in calculating the effect of the business cycle and trend upon the relative earnings of whites and nonwhites. As a cyclical variable, Freeman uses the deviation of real GNP from trend while Vroman uses the unemployment rate. The more important difference is the manner in which they examine the acceleration in the earnings ratio that is apparent after 1964. In order to track this change, Freeman uses the cumulated expenditure per black worker by the EEOC, acknowledging that this is only an "index of activity" since it can hardly be argued that the EEOC was the generator of the change in the earnings ratio. On the other hand, Vroman used a single acceleration term, equal to 0 prior to 1965,1 in 1965, 2 in 1966, and so on. In Vroman's equation, that acceleration term eliminates the significance of the trend term, whereas the EEOC variable does not. This is of significance because, as Figure 1 makes clear, no positive trend is observed in the nonwhite-white earnings ratio for men prior to 1965. Indeed, not until 1967 did the ratio return to its level of the Korean war.

Vroman, using a very large sample drawn from social security records, calculated the trend and acceleration terms for North and South separately (the CPS was judged too small a sample for this purpose). To quote Vroman's findings: "For Black men in the North there was no measurable trendwise improvement in relative earnings between 1957 and 1969." The gains for men are found entirely in the South. Freeman indicates that he has run regressions for North and South separately and that "the developments after 1964 arose not from regional shifts but, rather, from intraregional income changes." However, Vroman's data show that the improvement in the earnings ratio within regions has been due entirely to improvements in the South, presumably reinforced by interregional migration. Clearly, there has been significant progress in the South, but no one would assert that discriminatory barriers have "virtually collapsed" there. 
When Freeman considers the cohort earnings ratios, shown in Table 3, he does not, of course, account for the peculiar effect of the southern region, nor does he account for the fact that the years 1949, 1959, and 1969 were successively better years for overall economic activity. Now, since he has already indicated the greater cyclical sensitivity of nonwhite earnings, it would follow that the nonwhite-white earnings ratio would improve if the earnings trajectories were parallel. Hence, the observed parallelism of the cohort ratios should be adjusted for both regional and business cycle effects.

The problem is that parallel trajectories should not be expected for those who are subject to different initial positions, quite aside from questions of race. Lower-status jobs are known to have trajectories of lower amplitude and since nonwhites are demonstrably forced to occupy these jobs, it is peculiar that Freeman accepts so uncritically the apparent parallelism of earnings trajectories.

Robert E. Hall: One measure of the importance of a paper is how much it changes the reader's opinion about a subject. I must say my opinion was changed quite a bit by reading Freeman's paper. To provide some perspective on the issue of the economic status of blacks, I shall begin by outlining the "standard view"-in other words, what I would have said about the subject before reading this paper.

According to that view, while some relative increase in black incomes has occurred, considerable room for improvement still remains. Much of the progress has been associated with migration from the South, which is now rapidly coming to an end. Also, a prolonged economic expansion during the sixties helped blacks; and that too has been halted. And finally, although civil rights activity has achieved some progress, that component was quickly undone by the 1970-71 recession.

The standard picture becomes more disturbing when it focuses on the labor market situation of black individuals rather than on aggregates. Paradoxically, blacks start out in the labor market more or less at a point of equality with whites. But as time passes, they don't advance up the promotion ladder, and instead remain in bad jobs while whites move upward. This deterioration over the life cycle in the labor market position of blacks relative to whites is an integral part of the standard view.

But Freeman contends that every single point in this standard view is completely wrong. First of all, the important part of recent progress is not migration from low-wage to high-wage parts of the country, but rather 
rapid wage increases in the low-wage regions. Furthermore, Freeman tells us that the economic expansion of the sixties, although significant, explains only a small portion of the economic improvement of blacks. When influences in the sixties are separated into a cyclical component and a civil rights component, the latter predominates. Consequently, according to Freeman, black progress in the sixties is explained principally by civil rights activity rather than by cyclical expansion. These results must give pause to those who believe that, by and large, government attempts to affect the nature of society have perverse effects. If we believe the results of this paper, we must conclude that the 1960s witnessed a remarkably successful intervention of the federal government into the market system with a dramatic, favorable effect on a disadvantaged minority. It is an extremely optimistic set of conclusions. I am impressed by the force of the results, although I'm not sure I accept all of the interpretations and conclusions.

I might mention a few instances in which Freeman's results can be interpreted less optimistically. One involves his particularly interesting views concerning the age profile of earnings. The black-white income ratio, at any point in time, is lower for older people than younger ones. But Freeman convinces me that it is a mistake to attribute this relative deterioration of black earnings over the life cycle simply to an adverse "age effect." The combined cross-sectional and time series data exhibited in the paper indicate a "vintage effect" is really at work. The relative disadvantage of a black worker depends on when he was educated and when he entered the labor market. Older blacks are more disadvantaged relatively because their "vintage" was poorly educated and subject to greater discrimination in their earlier years-not because they are older. Once a given vintage enters the labor force, its relative position does not deteriorate as it ages. Thus, Freeman dismisses the adverse age effect.

The same experience can be explained in an alternative way: There is an unfavorable age effect but it is approximately canceled out by a favorable "time effect." This explanation implies, for example, that black men aged 35 in 1960 got some benefit from civil rights activity during the sixties (the favorable time effect)-enough to prevent the relative deterioration that would have come from the age effect as they reached 45 in 1970. This analysis is subject to a fundamental identification problem. Freeman's interpretation may well be right. But if civil rights activity produced a favorable time effect that counterbalanced a generally unfavorable age effect, the 
outlook for the future would have to be less optimistic, because the time effect might halt or even be reversed in the future. Much of Freeman's optimism rests on his interpretation that vintage, and not time, effects are primarily responsible for the economic progress of blacks.

Finally, one might question Freeman's interpretation of the impact of the prolonged economic expansion of the sixties. Freeman measures cyclical impact by the position of real GNP relative to trend. By that standard, the 1961-69 expansion could not have affected black incomes much more favorably than previous expansions; hence, some other explanation-like the EEOC variable-must be invoked to account for the unusually large advances in the relative economic position of blacks during that period. But the extraordinary duration of that expansion might have produced an unusual improvement in mobility. And the influence of civil rights activity might have been so complementary with the prolonged cyclical expansion that it is impossible to allocate the credit between them. It might be safer to conclude tentatively that the two factors, economic expansion and civil rights activity, were operating together.

Richard Freeman: In response to R. A. Gordon's objection to my simpleminded regressions, let me explain that my Table 1 was meant merely to summarize crudely the average trend and cyclical influences of the past generation. I wanted to provide a descriptive background for the analysis of subperiods and causal forces in the rest of the paper.

The general tenor of critical comments-that I may have overstated the case for improvement in the black economic status-is based on a comparison of changes in the black position with the "ideal" state of economic parity by race. The measuring rod that I use to evaluate recent progress is not this ideal but rather nearly one hundred years of little or no relative gain. It is the contrast of a persistence of black-white differences from 1890 to 1960, save for the World War II period for men and the late 1950s for women, that makes the developments of the 1960s remarkable.

One criticism that merits attention is Duran Bell's comment that Table 3 compares data taken from years of different cyclical positions. Where possible, I compared the same calculations for 1969 and 1971 (a period over which unemployment nearly doubled) and got the same basic results. I would like to make a correction for cyclical effects, but unfortunately I don't have enough information to determine their magnitude for various 
age groups. Bell's comment on Vroman's regional finding of virtually no trend improvement for black men in the North raises two issues: the concordance between social security, CPS, and Census data; and the accuracy of the Vroman regressions in evaluating cyclical effects. Vroman has explained the upward movement of relative male incomes in the North over the period from 1957 to 1969 by a cyclical variable. I believe the cyclical effect is overstated due to the limited coverage of years; relative black male incomes have not fallen in the post-1969 recession in the North and, according to CPS data, do not show such great cyclical effects over longer time periods, such as 1953-71. The experiment that tests my interpretation of the 1960s versus the cyclical explanation will come in the next recession; if black male incomes decline to previous levels relative to whites, I lose; if not, I win.

Again, I confess that I couldn't explain the decline in participation rates of black men. It is a very important development that requires further research. I suspect that this phenomenon is somehow related to changes in the family structure among blacks. Since men in any age group who do not head families have significantly lower participation rates than men who do, the decline in the proportion of black families headed by men should have a depressing effect on the overall participation rate for black men.

My conclusions about the overall importance of civil rights activity are admittedly based on small pieces of evidence, but on lots of pieces. I did, in fact, try the arithmetic progression variable beginning after 1965, as Duran Bell suggests, as an alternative to the civil rights variable; it works about as well, but it leaves open the question of what made things change so strongly after 1964. I was impressed that so much of the recent improvement in the economic status of blacks can be traced to increases in income ratios within the South, as shown in Table 2. Most of the EEOC activity was concentrated in the South and, in my opinion, deserves some of the credit for this improvement. Hall's suggestion that the expansion in the sixties may have had greater equalizing effects than previous economic expansions intrigues me, but I know no way to test it against the hypothesis that government activity was the principal agent for the economic improvement. A lot of other developments-court cases, reform pressures on the unions and the construction industry, and the like-indicate that government activity played an important role (with the valuable support of an expanding economy) in enabling blacks to achieve greater economic advances than ever before. 


\section{General Discussion}

Freeman's paper evoked a particularly spirited discussion. His findings clearly impressed the panel. Nonetheless, many participants raised unsettled issues or offered alternative explanations or contrary evidence that pointed to less optimistic-or more tentative-conclusions than those presented by Freeman.

Wayne Vroman found it difficult to reconcile the evidence of much greater progress for black women than for black men with the large role Freeman attributed to EEOC. Most EEOC activity, in Vroman's judgment, was directed toward improving employment opportunities for black men rather than women. He also questioned the consistency of Freeman's interpretation that relative incomes within given cohorts have been essentially stable over time and his finding of no upward movement between 1949 and 1959 in the aggregate relationship between black and white earnings. If, as time passes, each young black cohort entering the labor force possesses a greater degree of skill and education than the preceding one and if the relative income of a cohort does not deteriorate as it ages, then the aggregate black-white earnings ratio should have increased between 1949 and 1959.

Paul Samuelson particularly questioned the tremendous improvement in the economic status of black women, and especially the evidence that black female college graduates now earn more than their white counterparts. His interpretation differed from Freeman's. He suggested that the continuity of employment can be a critically important variable in explaining earnings differentials; black women may tend to remain in the labor force for long consecutive periods while white women move in and out. In that event, even if discrimination erodes the incomes of black women relative to whites with the same experience, black women could appear to be faring better. Indeed, the desperate condition of black family finances may have forced black women to stay in the labor market for a long period of time.

On two key issues, Richard Szal reported findings that sharply disagreed with Freeman's. In Szal's statistical analysis, the low unemployment rates of the late sixties explained most of the improvement in relative black incomes during that period, leaving only a very small influence to be attributed to the special effects of civil rights activity after 1964. In his work 
with social security data on continuous work experience within cohorts, he found that earnings of nonwhite females decline relative to those of white females as the groups get older.

R. J. Gordon offered some further caveats on the interpretation of gains in the relative incomes of black women. To the extent that they achieve monetary income gains at the expense of neglecting their homes and children, a substantial discount should be applied in assessing the relative income gains. He also stressed the importance of the movement out of domestic service in the improved occupational status of black women; they were leaving the worst jobs, rather than moving into particularly good ones.

On the more general question of the deterioration over time of relative incomes within cohorts, Gordon stressed the need for future research on whether the new generation of college-educated blacks will experience discrimination that impedes promotion and advancement. He suggested that enough data should be available to determine whether black college graduates hired by the large corporations in the past six years or so have maintained their incomes relative to whites with the same work experience.

R. A. Gordon expanded his remarks on the usefulness of the dual labor market theory in illuminating the economic progress of blacks. He felt that analysis of labor market segmentation and of the barriers that prevent blacks from obtaining better jobs could be more fruitful than Becker's concept of the "demand for discrimination" combined with Freeman's "supply responsiveness." Freeman felt the difference was largely semantic. The removal of labor market barriers improves both access and wage rates for blacks; he preferred to concentrate on the rise in wage rates, while dual labor market theorists stress the easier access.

Robert Hall noted that Becker's concept emphasizes the atomistic nature of discrimination as a characteristic of individual tastes, in the face of strong evidence of social pressures that forced whites to discriminate whether or not they personally shared those tastes. Hall suspected that, in the absence of such pressures, a sizable group of nondiscriminating entrepreneurs would have hired black workers and "arbitraged out" any major income differentials. Paul Samuelson suggested that Becker's conceptual framework wasn't so much wrong as it was empty; "tastes for discrimination" are not an explanation of behavior but merely a ghost that gets blamed for observed events.

Responding to Hall and Samuelson, Freeman agreed that demand for discrimination was an incomplete analysis. It had to be supplemented 
(although, he felt, not necessarily supplanted) by invoking collusion and coercion. He pointed out that the decline in discrimination after 1964 did not have to be explained arbitrarily by a change in tastes for discrimination, but could be accounted for by a change in the price of discrimination, reflecting observable penalties imposed by the government.

R. J. Gordon contended that the decline in the participation rate of black adult males was no mystery, in light of the failure of their relative incomes to improve. Many of them could well have become discouraged and dropped out of the labor force. Hyman Kaitz suggested that the large increase in welfare benefits also may have had a depressing influence on the participation rates of black men.

James Blackman felt that the black migration out of the South may have contributed to the large gains in relative incomes of blacks remaining in the region. That migration reduced the supply of black workers and presumably helped raise capital-labor ratios in the South. R. J. Gordon noted that the same reasoning might help explain the lack of improvement in relative incomes for black males in the North. The migrants raised the supply of relatively unskilled black labor in the North, thus holding down wage rates and average incomes there. 